University of Nebraska - Lincoln

DigitalCommons@University of Nebraska - Lincoln

$10-2020$

\title{
Economics of herbicide programs for weed control in conventional, glufosinate, and dicamba/glyphosate-resistant soybean across Nebraska
}

\author{
Adam M. Striegel \\ Kent M. Eskridge \\ Nevin C. Lawrence \\ Stevan Knezevic \\ Greg R. Kruger
}

See next page for additional authors

Follow this and additional works at: https://digitalcommons.unl.edu/agronomyfacpub

Part of the Agricultural Science Commons, Agriculture Commons, Agronomy and Crop Sciences Commons, Botany Commons, Horticulture Commons, Other Plant Sciences Commons, and the Plant Biology Commons

This Article is brought to you for free and open access by the Agronomy and Horticulture Department at DigitalCommons@University of Nebraska - Lincoln. It has been accepted for inclusion in Agronomy \& Horticulture -Faculty Publications by an authorized administrator of DigitalCommons@University of Nebraska - Lincoln. 
Authors

Adam M. Striegel, Kent M. Eskridge, Nevin C. Lawrence, Stevan Knezevic, Greg R. Kruger, Christopher A.

Proctor, Gary Hein, and Amit J. Jhala 


\title{
Economics of herbicide programs for weed control in conventional, glufosinate, and dicamba/glyphosate-resistant soybean across Nebraska
}

\author{
Adam Striegel, ${ }^{1}$ Kent M. Eskridge, ${ }^{2}$ Nevin C. Lawrence, ${ }^{3}$ \\ Stevan Z. Knezevic, ${ }^{1}$ Greg R. Kruger, ${ }^{1}$ Christopher A. Proctor, ${ }^{1}$ \\ Gary L. Hein, ${ }^{4}$ and Amit J. Jhala ${ }^{1}$
}

\begin{abstract}
1 Department of Agronomy and Horticulture, University of Nebraska-Lincoln, Lincoln, NE 68583

2 Department of Statistics, University of Nebraska-Lincoln, Lincoln, NE 68583

3 Panhandle Research and Extension Center, University of Nebraska-Lincoln, Scottsbluff, NE 69361

4 Department of Entomology, University of Nebraska-Lincoln, Lincoln, NE 68583

Correspondence Amit J. Jhala, Dep. of Agronomy and Horticulture, University of NebraskaLincoln, Lincoln, NE, 68583, USA. Email: Amit.Jhala@unl.edu
\end{abstract}

ORCID Amit J. Jhala https://orcid.org/0000-0001-8599-4996

\begin{abstract}
Despite widespread adoption of dicamba/glyphosate-resistant (DGR) soybean [Glycine $\max ($ L.) Merr.] in Nebraska and across the United States in recent years, economic information comparing herbicide programs with glufosinate-resistant (GLU-R) and conventional soybean is not available. The objectives of this study were to evaluate weed control efficacy, crop safety, gross profit margin, and benefit/cost ratios of herbicide programs with multiple sites of action in DGR, GLUR, and conventional soybean. Field
\end{abstract}

Published in Agronomy Journal 112 (2020), pp 5158-5179.

DOI: $10.1002 /$ agj2.20427

Copyright (C) 2020 by the Authors. Agronomy Journal is copyright (C) 2020 American Society of Agronomy. Published by Wiley. Used by permission.

Submitted 18 April 2020; accepted 20 August 2020; published 20 October 2020. 
experiments were conducted in 2018 and 2019 at three irrigated and two rain-fed locations across Nebraska, for a total of 10 site-years. Herbicides applied pre-emergence (PRE) that included herbicides with three sites of action provided $85-99 \%$ control of common lambsquarters (Chenopodium album L.), Palmer amaranth (Amaranthus palmeri S. Watson), velvetleaf (Abutilon theophrasti Medik.), and a mixture of foxtail (Seteria spp.) and Poaceae species. Pre-emergence herbicides evaluated in this study provided $72-96 \%$ weed biomass reduction and $61-79 \%$ weed density reductions compared with the nontreated control. Herbicides applied post-emergence (POST; dicamba plus glyphosate, glyphosate, glufosinate, and acetochlor plus clethodim plus lactofen) provided 93-99\% control of all weed species $28 \mathrm{~d}$ after POST (DAPOST). Herbicides applied POST provided $89-98 \%$ weed biomass reduction and $86-96 \%$ density reduction at 28 DAPOST. For individual site-years, yield was often similar for PRE followed by POST herbicide programs in herbicide-resistant (HR) and conventional soybean. Gross profit margins and benefit/cost ratios were higher in HR soybean than in conventional soybean, although price premiums for conventional soybean can help compensate for increased herbicide costs.

\section{Core Ideas}

- Weed control and yield were similar for most herbicide programs tested in this study.

- Gross profit margin was highest in herbicide-resistant soybean traits.

- Premiums for conventional soybean can compensate increased herbicide cost.

Abbreviations:

DAPOST, days after post-emergence application; DAPRE, days after pre-emergence application; DGR, dicamba/glyphosate-resistant; fb, followed by; GLU-R, glufosinateresistant; GR, glyphosate resistant; HR, herbicide-resistant; POST, post-emergence; PPO, protoporphyrinogen oxidase; PRE, pre-emergence; SOA, site of action

\section{Introduction}

Over the last few decades, commercialization of herbicide-resistant (HR) crops has led to changes in weed management strategies deployed in agronomic crop production systems in the United States. Herbicide-resistant crops provide flexibility to apply nonselective, postemergence (POST) herbicides for broad-spectrum weed control, and their adoption rates in the United States have remained high since 2014, with 90 and $94 \%$ of domestic corn (Zea mays L.) and soybean [Glycine max (L.) Merr.] acreage, respectively (USDA-ERS, 2018). In recent years, soybean cultivars resistant to multiple herbicide sites of 
action (SOA) have been commercialized. These cultivars stack existing glyphosate-resistant (GR) or glufosinate-resistant (GLU-R) traits with synthetic auxin herbicide 2,4-D (2,4-dichlorophenoxyacetic acid) or dicamba (3,6-dichloro-2-methoxybenzoic acid) resistance or provide resistance to isoxaflutole, a hydroxyphenyl-pyruvate-dioxygenase- inhibiting herbicide (Beckie, Ashworth, \& Flower, 2019). The use of multiple HR soybean cultivars provides producers additional weed management options; however, confirmation of 48 GR weed species globally and 17 GR species in the United States (Heap, 2020) serve as a reminder of the effects poor stewardship and over-reliance on a single herbicide SOA can have for the evolution of HR weeds. Additionally, it emphasizes the critical role herbicide stewardship will continue to play in preserving the utility of new multiple HR trait technologies, particularly in no-till corn-soybean cropping systems (Gage, Krausz, \& Walters, 2019).

In 2015 , a statewide survey of corn and soybean producers reported that $60 \%$ had incorporated the use of soil-applied residual herbicides in soybean to manage GR weeds (Sarangi \& Jhala, 2018). In Nebraska, six GR weed species have been confirmed: common ragweed (Ambrosia artemisiifolia L.), waterhemp [Amaranthus tuberculatus (Moq.) J. D. Sauer], giant ragweed (Ambrosia trifida L.), kochia [Bassia scoparia (L.) A. J. Scott], horseweed (Erigeron canadensis L.), and Palmer amaranth (Amaranthus palmeri S. Watson) (Knezevic et al., 2020; Sarangi \& Jhala, 2018). Integration of pre-emergence (PRE) herbicide use by soybean producers in Nebraska is similar to national trends, which have seen PRE herbicide use increase from 25 to $70 \%$ of soybean acreage in the United States from 2000 to 2015 (Peterson, Collavo, Ovejero, Shivrain, \& Walsh, 2018). A 2015 survey in Nebraska revealed that producers relied primarily on protoporphyrinogen oxidase (PPO)-inhibiting and acetolactate synthase-inhibiting herbicides as PRE herbicides in soybean. The most commonly used herbicides were cloransulam-methyl plus sulfentrazone and flumioxazin alone or in tank-mixture with chlorimuronethyl and thifensulfuron-methyl (Sarangi \& Jhala, 2018). As more producers adopt soil-applied residual herbicides at crop planting, there will be opportunities to improve herbicide stewardship through the use of robust herbicide rotations in combination with tank-mixtures of herbicides with multiple effective SOAs (Beckie \& Reboud, 2009; Busi, Powles, Beckie, \& Renton, 2019). 
Previous research has indicated that the combination of herbicide rotation and tank-mixtures can delay the evolution of new HR weed biotypes (Beckie et al., 2019; Busi et al., 2019; Gage et al., 2019), and these are endorsed as best management practices in both nonintegrated and integrated weed management programs (Knezevic \& Cassman, 2003; Norsworthy et al., 2012). Research on HR weed populations has also shown that tank-mixtures with multiple effective SOAs can control GR weed biotypes, such as common ragweed (Barnes, Knezevic, Sikkema, Lindquist, \& Jhala, 2017; Byker et al., 2018), waterhemp (Jhala, Sandell, Sarangi, Kruger, \& Knezevic, 2017), horseweed (Chahal \& Jhala, 2019), and kochia (Sbatella et al., 2019). Similarly, tank-mixtures with multiple effective SOAs have been shown to control other HR weed biotypes, such as PPO-inhibitor resistant Palmer amaranth (Schwartz-Lazaro, Norsworthy, Scott, \& Barber, 2017) or atrazine/hydroxyphenyl-pyruvate-dioxygenase inhibitor-resistant Palmer amaranth (Chahal \& Jhala, 2019).

In response to concerns about resistance to soil-applied residual herbicides, pesticide manufacturers have commercialized "ready-touse" pre-mixture formulations of soil-applied residual herbicides with multiple SOAs for use in many agronomic crops, including soybean (Norsworthy et al., 2012). Although stewardship risks associated with application of pre-mixture products below labeled rates exist (Beckie \& Harker, 2017; Owen, 2016), widespread adoption and frequent use of pre-mixture products warrants further study and comparison, particularly in soybean with multiple HR traits. Assessments of economic benefits of incorporating PRE herbicide programs in conventional, GR, and glufosinate-resistant (GLU-R) (LibertyLink) soybean systems were examined in a multiyear study conducted in Missouri comparing combinations of PRE and/or POST herbicide programs (Rosenbaum, Massey, \& Bradley, 2013). Results from this study indicated that the use of PRE herbicide programs provided the best opportunities for weed control and higher net returns; however, PRE followed by (fb) POST programs provided greater control of waterhemp regardless of soybean HR trait (Rosenbaum et al., 2013). Likewise, a multiyear study in Nebraska compared pre-plant, PRE, and/or POST herbicide programs for control of GR common ragweed and reported that pre-plant fb POST and PRE fb POST herbicide programs provided the highest and most economical control of GR common ragweed in GLUR soybean (Barnes et al., 2017). 
As producers struggle to manage GR weeds using POST herbicides, many have considered rotation to dicamba/glyphosate-resistant (DGR) or GLU-R soybean traits (Werle, Oliveira, et al., 2018). In a 2015 statewide survey conducted in Nebraska, 34\% of row crop producers responded positively toward rotation (Sarangi \& Jhala, 2018). The GLU-R cultivars currently make up about $20 \%$ of soybean grown in the United States. This has increased substantially over the last 5 yr due to the growing need to control GR weeds and troublesome pigweed (Amaranthus spp.) species (Beckie et al., 2019). However, adoption of GLU-R soybean in Nebraska has historically been $5.2 \%$ or less of total soybean production (Sarangi \& Jhala, 2018). Glufosinate applied alone or in tankmixture has been shown to be effective for controlling GR weeds such as waterhemp, Palmer amaranth, or common ragweed and remains a viable POST option for producers (Barnes et al., 2017; Butts et al., 2016; Jhala et al., 2017; Schultz, Myers, \& Bradley, 2015).

Dicamba/glyphosate-resistant (Roundup Ready 2 Xtend) soybean received USEPA approval in 2017. A statewide survey of Nebraska soybean producers indicated that $8.7 \%$ of total soybean planted was DGR soybean in 2017 (Werle, Oliveira, et al., 2018). Popularity of DGR soybean cultivars both in Nebraska and the United States has increased since their introduction. Currently, DGR soybeans are estimated to be the most commonly planted soybean HR trait in the United States (Anonymous, 2020). Beckie et al. (2019) estimated that DGR soybean has at least a $50 \%$ market share in the United States.

Producers are continually under pressure to reduce production costs. Studies comparing weed control, crop yield, and economic return in conventional and HR soybean have been conducted (Owen et al., 2010; Peterson, Thompson, \& Minihan, 2017; Rosenbaum et al., 2013); however, these studies did not focus on commercially available pre-mixture PRE herbicide products with three SOAs or the economic analysis of DGR, GLU-R, and conventional soybean systems. The objectives of this study were to evaluate PRE fb POST herbicide programs with multiple SOA in DGR, GLU-R, and conventional soybean for weed control efficacy, crop safety, gross profit margin, and benefit/cost ratio at five locations across Nebraska. 


\section{Materials and methods}

\subsection{Study locations}

In 2018 and 2019, field experiments were conducted in northeastern (Concord), eastern (Lincoln), south-central (Clay Center), west-central (North Platte), and western (Scottsbluff) Nebraska at University of Nebraska-Lincoln Research and Extension Centers and Agricultural Laboratories under irrigated (Clay Center, North Platte, and Scottsbluff) and rain-fed (Concord and Lincoln) conditions. For all site-years, experiments were established in fields following a corn-soybean crop rotation. All locations received reduced tillage or an early spring pre-plant herbicide application to control winter annual weeds. Experimental sites were primarily infested with common lambsquarters (Chenopodium album L.); Palmer amaranth; velvetleaf (Abutilon theophrasti Medik.); and a mixture of bristly foxtail [Setaria verticillata (L.) Beauv.], giant foxtail (Setaria faberi Herrm.), green foxtail [Setaria viridis (L.) P. Beauv.], yellow foxtail [Setaria pumila (Poir.) Roem. \& Schult.], large crabgrass [Digitaria sanguinalis (L.) Scop.], and field sandbur (Cenchrus spinifex Cav.).

\subsection{Experimental design}

Field experiments were arranged in a split-block design with four replications (Federer \& King, 2006). The PRE herbicide program (Table 2) was the whole plot factor in a randomized complete block, and soybean-cultivar/trait [Roundup Ready 2 Xtend (RR2X), LibertyLink, conventional] with subsequent POST herbicide program (Table 2) was the subplot factor. This resulted in seven nonstandard incomplete "column" blocks, each containing only four of the seven PRE herbicide treatments across four replications. The incomplete blocking factor was added to accommodate experimental locations without access to research plot/ packet planters and to simplify field operations. Plot size was $3 \mathrm{~m}$ wide (four soybean rows spaced $0.75 \mathrm{~m}$ apart) by $9 \mathrm{~m}$ in length. To protect dicamba-sensitive cultivars from direct spray drift, DGR soybean was planted flanking either side of plots receiving POST herbicide applications of dicamba and treated with POST applications of glyphosate, resulting in a 3-m buffer between dicamba applications and dicambasensitive cultivars. In addition to providing a 3-m buffer, glyphosate was 
Table 1 Soybean cultivars, planting dates, and pre-emergence (PRE) and postemergence (POST) herbicide application dates in field experiments conducted across five locations in Nebraska to determine economics of herbicide programs for weed control in conventional, glufosinate-resistant, and dicamba/glyphosate-resistant soybean in 2018 and 2019.

\begin{tabular}{|c|c|c|c|c|c|c|}
\hline $\begin{array}{l}\text { Study } \\
\text { location }^{a}\end{array}$ & $H R$-trait ${ }^{b}$ & Cultivar & Company & Planting date & $\begin{array}{l}\text { PRE herbicide } \\
\text { application date }\end{array}$ & $\begin{array}{l}\text { POST herbicide } \\
\text { application date }\end{array}$ \\
\hline \multirow[t]{3}{*}{ Clay Center } & DGR & S29-k3x NK & Syngenta Seeds & $\begin{array}{l}7 \text { May } 2018, \\
15 \text { May } 2019\end{array}$ & $\begin{array}{l}7 \text { May } 2018, \\
15 \text { May } 2019\end{array}$ & $\begin{array}{l}4 \text { June } 2018, \\
13 \text { June } 2019\end{array}$ \\
\hline & GLU-R & P31T02L & Corteva AgriScience & & & \\
\hline & CON & A3253 & Bayer Crop Science & & & \\
\hline \multirow[t]{3}{*}{ Concord } & $\mathrm{DR}$ & $27 \mathrm{MX} 8 \mathrm{NK}$ & Syngenta Seeds & $\begin{array}{l}5 \text { June } 2018 \\
6 \text { June } 2019\end{array}$ & $\begin{array}{l}6 \text { June 2018; } \\
8 \text { June2019 }\end{array}$ & $\begin{array}{l}20 \text { July 2018, } \\
11 \text { Jul } 2019\end{array}$ \\
\hline & GLU-R & CZ2601LL & BASF Corporation & & & \\
\hline & $\mathrm{CON}$ & Р29T50 & Corteva AgriScience & & & \\
\hline \multirow[t]{3}{*}{ Lincoln } & DGR & S29-k3x NK & Syngenta Seeds & $\begin{array}{l}13 \text { May } 2018, \\
17 \text { May } 2019\end{array}$ & $\begin{array}{l}11 \text { May } 2018, \\
17 \text { May } 2019\end{array}$ & $\begin{array}{l}11 \text { June 2018, } \\
21 \text { June } 2019\end{array}$ \\
\hline & GLU-R & P31T02L & Corteva AgriScience & & & \\
\hline & CON & A3253 & Bayer Crop Science & & & \\
\hline \multirow[t]{3}{*}{ North Platte ${ }^{d}$} & DGR & $28 \times T 58$ & Loveland Products & $\begin{array}{l}20 \text { May } 2018 \\
31 \text { May } 2019\end{array}$ & $\begin{array}{l}18 \text { May } 2018 \\
4 \text { June } 2019\end{array}$ & $\begin{array}{l}26 \text { June } 2018 \\
11 \text { July } 2019\end{array}$ \\
\hline & GLU-R & CZ2601LL & BASF Corporation & & & \\
\hline & CON & A3253 & Bayer Crop Science & & & \\
\hline \multirow[t]{4}{*}{ Scottsbluffd } & DGR & AG20X7 & Bayer Crop Science & $\begin{array}{l}21 \text { May } 2018, \\
5 \text { June } 2019\end{array}$ & $\begin{array}{c}21 \text { May 2018, } \\
5 \text { June } 2019\end{array}$ & $\begin{array}{l}18 \text { July } 2018 \\
26 \text { July } 2019\end{array}$ \\
\hline & GLU-R & H2OL3 & Hefty Seed Company & & & \\
\hline & CON & U11-917032 & Husker Genetics & & & \\
\hline & & A2035 & Bayer Crop Science & & & \\
\hline
\end{tabular}

a. Soil tests for the study locations: Clay Center (hastings silt loam with pH $6.5 ; 17 \%$ sand, $58 \%$ silt, and $25 \%$ clay; $3.0 \%$ organic matter [OM]); Concord (silt loam with pH 6.4; $20 \%$ sand, 54\% silt, 26\% clay; $3.5 \%$ OM; and cation exchange capacity [CEC] of 23.8); Lincoln (silt clay loam with pH 5.6; $19 \%$ sand, $54 \%$ silt, $27 \%$ clay; $3.3 \%$ OM); North Platte (sandy loam with pH 7.5; $57 \%$ sand, $32 \%$ silt, $11 \%$ clay; $2.1 \%$ OM; and CEC of 11.7 ); Scottsbluff (sandy loam with pH $7.5 ; 78 \%$ sand, $8 \%$ silt, $13 \%$ clay; and CEC of 7.8).

b. CON, conventional; DGR, dicamba/glyphosate-resistant; GLU-R, glufosinate-resistant; POST, Post-emergent herbicide; PRE, Pre-emergent herbicide.

c. Soybean cultivar A3253 was replanted on 11 June 2019 due to poor initial crop stand.

d. Prior to planting, $122 \mathrm{~kg} \mathrm{~N}$ and $45 \mathrm{~kg} \mathrm{P}_{2} \mathrm{O}_{5}$ ha $^{-1}$ were broadcasted, with $4.7 \mathrm{~L} \mathrm{ha}^{-1}$ of $6 \%$ chelated iron applied in-furrow to reduce iron chlorosis.

\author{
applied POST in DGR soybean to represent the production practice of \\ planting DGR soybeans but not applying dicamba POST. Soybean culti- \\ vars were selected based on maturity group requirements for each lo- \\ cation (1.8-2.3 for Scottsbluff; 2.6-3.2 cultivar for Clay Center, Concord, \\ Lincoln, and North Platte) and iron chlorosis resistance for Scottsbluff. \\ Soybean cultivars were planted at 296,500 seeds ha ${ }^{-1}$ at Scottsbluff and \\ 333,500 seeds ha-1 (De Bruin \& Pedersen, 2008; Specht, 2016) at other \\ locations (Table 1).
}


Table 2 Pre-emergence herbicide (PRE) and postemergence herbicide (POST) herbicide programs in field experiments conducted across five locations in Nebraska to determine economics of herbicide programs for weed control in conventional, glufosinate-resistant, and dicamba/glyphosate-resistant soybean in 2018 and 2019.

\begin{tabular}{|c|c|c|c|c|c|c|}
\hline Herbicide program & Rate & Trade name & Manufacturer & Adjuvants $^{a}$ & $\begin{array}{l}\text { Herbicide } \\
\text { program } \\
\text { cost }^{b}\end{array}$ & $\begin{array}{l}\text { Nozzles, } \\
\text { carrier } \\
\text { volume }\end{array}$ \\
\hline & $\mathrm{g}$ ai or ae ha-1 & & & & US\$ ha-1 & $\mathrm{L} \mathrm{ha}^{-1}$ \\
\hline \multicolumn{7}{|l|}{ Nontreated control } \\
\hline \multirow[t]{2}{*}{ Weed-free control } & 1,680 & Warrant & Bayer & & 118.04 & AIXR, 140 \\
\hline & 215 & Zidua Pro & BASF & & & \\
\hline \multicolumn{7}{|l|}{ PRE } \\
\hline \multirow{2}{*}{$\begin{array}{l}\text { Sulfentrazone/ } \\
\text { S-metolachlor } \\
+ \text { metribuzin }\end{array}$} & 1,960 & Authority Elite & FMC & & 134.25 & AIXR, 140 \\
\hline & 700 & Tricor 4F & UPI & & & \\
\hline $\begin{array}{l}\text { Chlorimuron/ } \\
\text { flumioxazin/ } \\
\text { thifensulfuron-methyl }\end{array}$ & 94 & Enlite & Corteva & & 58.30 & AIXR, 140 \\
\hline \multirow{2}{*}{$\begin{array}{l}\text { Flumioxazin/ } \\
\text { pyroxasulfone } \\
\text { + metribuzin }\end{array}$} & 160 & Fierce & Valent & & 83.66 & AIXR, 140 \\
\hline & 210 & Tricor 4F & UPI & & & \\
\hline $\begin{array}{l}\text { Chlorimuron/ } \\
\text { flumioxazin/metribuzin }\end{array}$ & 374 & Trivence & Corteva & & 73.48 & AIXR, 140 \\
\hline $\begin{array}{l}\text { Imazethapyr/ } \\
\text { pyroxasulfone/ } \\
\text { saflufenacil }\end{array}$ & 215 & Zidua Pro & BASF & & 77.92 & AIXR, 140 \\
\hline \multicolumn{7}{|l|}{ PRE fb POST } \\
\hline Dicamba + glyphosate & $560+1,540$ & $\begin{array}{l}\text { Xtendimax }+ \\
\text { Roundup } \\
\text { Powermax }\end{array}$ & Bayer & DRA,WC & 91.31 & TTI, 140 \\
\hline Glyphosate & 1,540 & $\begin{array}{l}\text { Roundup } \\
\text { Powermax }\end{array}$ & Bayer & AMS & 33.46 & AIXR, 140 \\
\hline Glufosinate & 656 & Liberty & BASF & AMS & 50.31 & $\mathrm{XR}, 187$ \\
\hline \multirow{2}{*}{$\begin{array}{l}\text { Acetochlor + clethodim } \\
+ \text { lactofen }\end{array}$} & 1,680 & Warrant & BayerValent & AMS, COC & 148.74 & AIXR, 140 \\
\hline & $119+220$ & $\begin{array}{l}\text { Select Max + } \\
\text { Cobra }\end{array}$ & & & & \\
\hline
\end{tabular}

Note. ai, active ingredient; ae, acid equivalent; AMS, ammoniumsulfate; COC, crop oil concentrate; DRA, drift reducing agent; fb, followed by; POST, Post-emergent herbicide; PRE, Pre- for pre-emergence herbicide; WC, non-AMS water conditioner.

a. AMS at $1-1.25 \%(\mathrm{wt} / \mathrm{v}), \mathrm{COC}$ at $1 \% \mathrm{v} / \mathrm{v}, \mathrm{DRA}$ at $0.5-1 \% \mathrm{v} / \mathrm{v}$ andWC at $1 \% \mathrm{v} / \mathrm{v}$ were mixed with POST herbicide treatments according to label recommendations.

b. Herbicide costs were averaged from three independent sources in Nebraska and include custom application: PRE (US\$17.30 ha 1 application 1), non-dicambacontaining POST (US\$18.94 ha ${ }^{-1}$ application 1), and dicamba-containing POST (US\$31.71 ha-1 application ${ }^{-1}$ ). 


\subsection{Herbicide treatments}

The PRE herbicides (Table 2) were applied at or following soybean planting (Table 1) at each experimental location with a $\mathrm{CO}_{2}$-pressurized backpack sprayer consisting of a four- or five-nozzle boom calibrated to deliver $140 \mathrm{~L} \mathrm{ha}^{-1}$ at $276 \mathrm{kPa}$ with AIXR 110015 flat-fan nozzles (TeeJet Spraying Systems Co.). For comparison, a nontreated (weedy) control and a weed-free control were included with weed-free control plots maintained by using herbicides and hand-weeding as needed. The POST herbicide programs (Table 2) were applied between 28 and $45 \mathrm{~d}$ after soybean planting, depending on site-specific weed pressure. The POST herbicides were applied with a $\mathrm{CO}_{2}$-pressurized backpack sprayer consisting of a four- or five-nozzle boom fitted with TeeJet AIXR or TTI flatfan nozzles calibrated to deliver $140 \mathrm{~L} \mathrm{ha}^{-1}$ or XR flat-fan nozzles at 187 $\mathrm{L} \mathrm{ha}^{-1}$ at $276 \mathrm{kPa}$, respectively (Table 2).

\subsection{Data collection}

Visual estimates of control of Palmer amaranth and waterhemp, common lambsquarters, velvetleaf, combined grasses, and other weed species were recorded at 14 and $28 \mathrm{~d}$ after PRE (DAPRE) and 14 and 28 $\mathrm{d}$ after POST (DAPOST) based on a $0-100 \%$ scale, where $0 \%$ represented no control and 100\% represented plant death. Soybean injury was also assessed at 14 and 28 DAPRE and 14 and 28 DAPOST using a similar $0-100 \%$ scale, where $0 \%$ represented no crop injury and $100 \%$ represented plant death. Density of individual weed species was recorded by counting the number of weeds in two $0.5-\mathrm{m}^{2}$ quadrats that were placed randomly in the center two soybean rows in each plot at 14 and 28 DAPRE and DAPOST and adjusted to plants $\mathrm{m}^{-2}$. Aboveground weed biomass was collected $1 \mathrm{~d}$ prior to POST herbicide applications and 28 DAPOST herbicide applications by randomly sampling two $0.5-\mathrm{m}^{2}$ quadrants from the center two soybean rows of each plot in which plants were cut at the soil surface and recording the weed species present in the biomass sample. Weed biomass samples were ovendried until constant weight and adjusted to grams weed biomass $\mathrm{m}^{-2}$. Percentages of aboveground weed biomass and density reductions relative to the nontreated control were calculated by using the following equation (Wortman, 2014): 


$$
Y=[(C-B) / C] \times 100
$$

where $C$ represents the weed biomass or density from the nontreated control plots, and $B$ represents the weed biomass or density from the treated plots. Crop stand was assessed at $28 \mathrm{~d}$ after PRE (DAPRE) herbicide application by counting the number of soybean plants present in 1 or $3 \mathrm{~m}$ of the center two rows, depending on study location. Weather data for each study location were collected by on-farm or High Plains Regional Climate Center Automated Weather Data Network weather stations, with cumulative precipitation received and average daily temperature recorded from 1 May to 31 Oct. 2018 and 2019. Soybean grain was harvested from the center two rows in each plot at maturity using a small-plot combine with grain weight and moisture content recorded and adjusted to $13 \%$.

\subsection{Economic analysis}

Gross profit margins and benefit/cost ratio were calculated to assess the profitability for each weed management program (combination of the herbicide program with the cost for herbicide-resistant or conventional soybean seed). Gross profit margin was calculated for each weed management program using the following equation (Sarangi \& Jhala, 2019):

$$
\text { Gross profit margin (US\$) }=(R-W)
$$

where $R$ is the gross revenue calculated by multiplying soybean yield for each treatment by the average price received for genetically modified (GM) HR soybean (US $\$ 0.30 \mathrm{~kg}^{-1}$ ) or non-GM soybean (US $\$ 0.35 \mathrm{~kg}^{-1}$ ), and $W$ is the total weed management program cost comprised of the average cost of herbicides and spray adjuvants for each treatment with custom application and the weighted average seed cost for the soybean cultivar/trait planted.

Average market price for GM soybean was derived from the cash prices received in Nebraska as reported by the USDA National Agricultural Statistics Service Information from September to December in 2018 and 2019 (USDANASS, 2019). The price for non-GM soybeans was 
calculated with estimated price premiums for non-genetically modified organism feed-grade soybean derived from 20 USDA Agricultural Marketing Service National Weekly Non-GMO/Genetically Engineered Grain Reports dating from September to December in 2018 and 2019 (USDAAMS, 2020).

Price estimates for herbicides and spray adjuvants were obtained from three independent commercial sources in Nebraska (Central Valley Ag Cooperative, Frontier Cooperative, Nutrien Ag Solutions) and averaged prior to economic analysis. Custom application price estimates from the previously listed sources were also obtained, with an average cost of US\$17.30 ha $^{-1}$ application $^{-1}$ for PRE herbicide programs, US\$18.94 ha-1 application ${ }^{-1}$ for nondicamba POST herbicide programs, and US\$31.71 ha application $^{-1}$ for POST herbicide programs containing dicamba.

For each treatment, $W$ included the weighted average seed costs for soybean cultivar/trait used in this study, which were adjusted based on planting density. Seed costs included associated technology fees for HR traits and commercially available discounts for volume and cash/prepay but did not include potential herbicide rebate programs. The benefit/cost ratios were calculated for each herbicide program using the following equation (Sarangi \& Jhala, 2019):

$$
\text { Benefit/cost ratio for a program(US\$/US\$) }=\left(R_{\mathrm{T}}-R_{\mathrm{C}}\right) / W
$$

where $R_{\mathrm{T}}$ is the overall gross revenue of each weed management program, $R_{\mathrm{C}}$ is the gross revenue for the nontreated control, and $W$ is equal to the cost for each weed management program including the cost of herbicides, spray adjuvants, custom application, and seed.

\subsection{Statistical analysis}

Statistical analysis was performed in R statistical software v. 3.6.1 (R Core Team, 2018) using the "lme4" package v. 1.1-21 (Bates, Machler, Bolker, \& Walker, 2015) and the "glmmTMB" package v. 1.0.0 (Brooks et al., 2017). Experimental data were analyzed with a combined analysis, excluding soybean yield, which was analyzed by site-year. In the combined model, the interaction of PRE herbicide program, POST herbicide program, and site-year were considered fixed effects, and the interaction 
of site-year with replication, replication by PRE, column, and column by POST herbicide were considered random effects. In the separated model, site-year interactions were removed from fixed and random effects.

Total aboveground weed biomass and density reductions, weed control, and crop injury ratings were $\log (x+1)$, square root, or logittransformed and fit to generalized linear mixed-effect models using glmmTMB functions with Gaussian (link = "identity") and beta (link = "logit") error distributions (Stroup, 2015). Final glmmTMB models were selected based on comparisons of dispersion parameter estimates and Akaike information criterion values, with $\log (x+1)$ or square root transformation with Gaussian error distribution selected for most response variables.

Soybean grain yield, plant stand, and weed density data were $\log (x+$ 1) or square root transformed and fit to linear mixed-effect models using the Imer function (Kniss \& Streibig, 2018). Final lmer models were selected based on a comparison of restricted maximum likelihood criterion at convergence values, with default or Nelder-Mead model optimizers used for most response variables.

Prior to conducting ANOVA, variance assumptions were tested by using Levene's tests (Wang et al., 2017) with the leveneTest function at $\alpha=.05$. Variables that failed variance assumptions were transformed, fit to glmmTMB and lmer models, and visually assessed for outliers and heterogeneity of variance by plotting residual values (Knezevic, Evans, Blankenship, Van Acker, \& Lindquist, 2002; Ritz, Kniss, \& Streibig, 2015). Normality assumptions were tested using Shapiro-Wilk tests with the shapiro.test function (Kniss \& Streibig, 2018).

The ANOVA was performed with "car" package v. 3.0- 6 (Fox \& Weisberg, 2019) using the Anova function. For glmmTMB models, ANOVA was conducted with Type III Wald Chi-Square Tests, whereas lmer models used Type III Wald F Tests. Treatment-estimated marginal means were separated with "emmeans" package v. 1.4.3 (Lenth, 2019) and "multcomp" package v. 1.4-11 (Hothorn, Bretz, \& Westfall, 2008) using the emmeans and cld functions (Kniss \& Streibig, 2018) at $\alpha=.05$, with Sidak method confidence-level adjustment and post hoc Tukey $P$ value adjustments. Following treatment means separation, data were back-transformed for the presentation of results. 
Results presented in this study exclude data from North Platte in 2018 due to a study-wide planter malfunction and Lincoln in 2019 due to flooding 10 DAPRE. Likewise, due to an 80\% defoliating hail event 29 DAPOST at Scottsbluff and a 60\% defoliating hail event 51 DAPOST (5 Aug. 2019) during the R5 soybean growth stage in Clay Center in 2019, results presented in this study for crop yield, gross profit margin, and benefit/cost ratio exclude data from these site-years.

\section{Results}

\subsection{Average daily temperature and precipitation}

Average daily temperatures during the 2018 and 2019 growing seasons for most study locations were similar to the 30-yr average, with the exception of Clay Center, which were slightly cooler (average temperature, $14.5^{\circ} \mathrm{C}$ ). Cumulative precipitation amounts recorded in 2018 and 2019 at each study location were similar or slightly exceeded the 30-yr average (Figure 1).

\subsection{Crop stand}

Soybean plant stand for locations at 28 DAPRE did not differ across PRE herbicide program $(P=.994)$, soybean HR trait and subsequent POST herbicide program $(P=.948)$, PRE by site-year $(P=.900)$, and PRE by POST $(P=.676)$ or PRE by POST by site-year $(P=.889)$, with a studywide average of 234,250 plants ha ${ }^{-1}$ (data not shown).

\subsection{Pre-emergence herbicide: Weed control, weed density, density reduction, and biomass reduction}

Across site-years, PRE herbicide programs provided 93-99\% control of Palmer amaranth, 92-99\% control of common lambsquarters, 87-94\% control of velvetleaf, and 81-97\% control of grass weed species (bristly foxtail, giant foxtail, green foxtail, yellow foxtail, large crabgrass, and field sandbur) at 28 DAPRE (Table 3). Aboveground weed biomass 

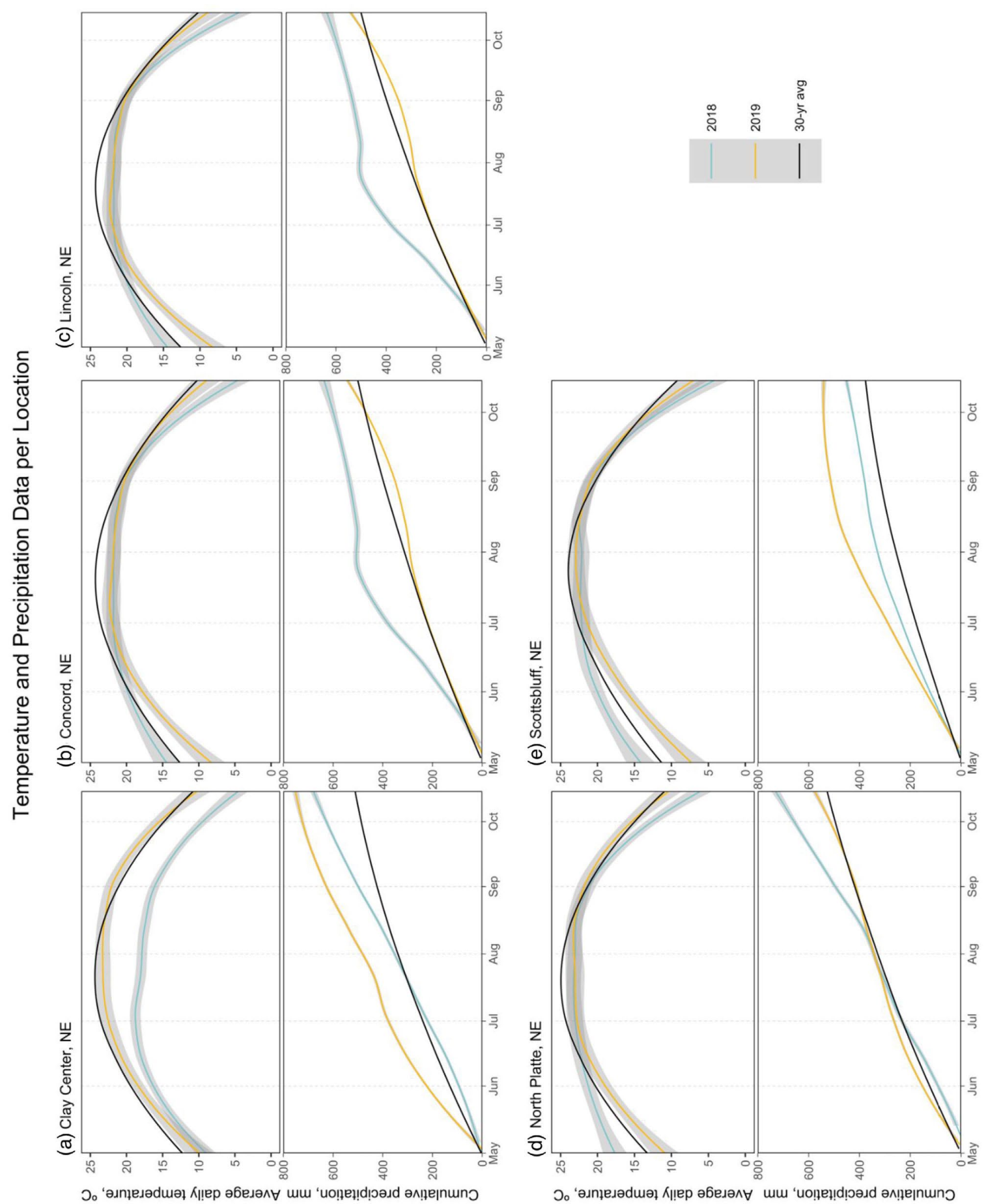

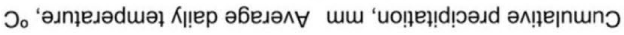

Figure 1 Average daily air temperature $\left({ }^{\circ} \mathrm{C}\right)$ and total cumulative precipitation $(\mathrm{mm})$ received during the 2018 and 2019 growing seasons compared with the 30-yr average for field experiments conducted across irrigated (A) Clay Center, NE; (D) North Platte, NE; and (E) Scottsbluff, NE and rainfed conditions in (B) Concord, NE and (C) Lincoln, $\mathrm{NE}$ to determine economics of herbicide programs in conventional, glufosinate-resistant, and dicamba/glyphosate-resistant soybean in Nebraska 
reduction at 28-45 DAPRE $(P<.001)$ showed that PRE herbicide programs offered similar weed biomass reduction relative to the nontreated control $\left(258 \mathrm{~g} \mathrm{~m}^{-2}\right)$ as the weed-free control (82\%) prior to hand removal, where sulfentrazone/S-metolachlor plus metribuzin provided $96 \%$ weed biomass reduction and imazethapyr/pyroxasulfone/saflufenacil and chlorimuron/flumioxazin/thifensulfuron provided 77 and $72 \%$ weed biomass reduction, respectively (Table 3). Palmer amaranth, common lambsquarters, velvetleaf, and the aforementioned grass weed species varied in density at 14 and 28 DAPRE, with most PRE herbicide programs providing similar total weed density reduction to the weedfree control (73\%), excluding chlorimuron/flumioxazin/thifensulfuron (61\%) (Table 4).

\subsection{Post-emergence herbicide: Weed control, weed density, density reduction, and biomass reduction}

At 14 and 28 DAPOST, most POST herbicide programs provided $\geq 87 \%$ control of Palmer amaranth, common lambsquarters, velvetleaf, and grass weed species (Table 5). Aboveground biomass reduction at 28 DAPOST was significant $(P<.001)$, with dicamba plus glyphosate, glyphosate, and glufosinate resulting in $\geq 97 \%$ reduction of total weed biomass relative to the nontreated control $\left(1,178 \mathrm{~g} \mathrm{~m}^{-2}\right)$. Weed biomass reduction was $89 \%$ for acetochlor plus clethodim plus lactofen (Table 5).

Density rates of Palmer amaranth, common lambsquarters, and grass weed species were similar $(P>.05)$ across POST herbicide programs 28 DAPOST with 0-1 plants $\mathrm{m}^{-2}$, whereas density of velvetleaf at 14 and 28 DAPOST and common lambsquarters at 14 DAPOST was significant $(P<$ .001), although only equal to 1 plant $\mathrm{m}^{-2}$ for acetochlor plus clethodim plus lactofen. Density of grassweed species at 14 DAPOST was not different (Table 6), and POST herbicide program was not significant for total weed density reduction at 28 DAPOST $(P=.832)$, with POST herbicide programs reducing total weed density $86-94 \%$ from densities present in the nontreated control (85 plants $\left.\mathrm{m}^{-2}\right)$. 
Table 3 Weed control at 14 and 28 days after pre-emergence herbicide application (DAPRE) in field experiments conducted across five locations in Nebraska to determine economics of herbicide programs in conventional, glufosinate, and dicamba/ glyphosate-resistant soybean in 2018 and 2019.

\begin{tabular}{|c|c|c|c|c|c|c|c|c|c|}
\hline \multirow[b]{2}{*}{ Herbicide programa } & \multicolumn{2}{|c|}{$\begin{array}{l}\text { Palmer } \\
\text { amaranth }\end{array}$} & \multicolumn{2}{|c|}{$\begin{array}{l}\text { Common } \\
\text { lambsquarters }\end{array}$} & \multicolumn{2}{|c|}{ Velvetleaf } & \multicolumn{2}{|c|}{ Grass species } & \multirow{2}{*}{$\begin{array}{l}\begin{array}{l}\text { Total } \\
\text { biomass }\end{array} \\
\text { reduction }\end{array}$} \\
\hline & $\begin{array}{l}14 \\
D A P R E\end{array}$ & $\begin{array}{l}28 \\
D A P R E\end{array}$ & $\begin{array}{l}14 \\
D A P R E\end{array}$ & $\begin{array}{l}28 \\
D A P R E\end{array}$ & $\begin{array}{l}14 \\
D A P R E\end{array}$ & $\begin{array}{l}28 \\
D A P R E\end{array}$ & $\begin{array}{l}14 \\
D A P R E\end{array}$ & $\begin{array}{l}28 \\
D A P R E\end{array}$ & \\
\hline & & & & & $\%$ & & & & L \\
\hline Nontreated control & 0 & 0 & 0 & 0 & 0 & 0 & 0 & 0 & 0 \\
\hline Weed-free control & 99 & 99 & 99 & 99 & 99 & 99 & 99 & 99 & $100 a c$ \\
\hline $\begin{array}{l}\text { Sulfentrazone/S-metolachlor } \\
+ \text { metribuzin }\end{array}$ & $98 a$ & $99 a$ & $96 a$ & $99 a$ & $92 a b$ & $92 a b c$ & $97 a$ & $97 a$ & $96 a b$ \\
\hline $\begin{array}{l}\text { Chlorimuron/flumioxazin/ } \\
\text { thifensulfuron-methyl }\end{array}$ & $94 a b$ & $93 b$ & $72 \mathrm{bc}$ & $90 b$ & $86 a b$ & $88 \mathrm{bc}$ & $84 a b$ & $81 c$ & $72 d$ \\
\hline $\begin{array}{l}\text { Flumioxazin/pyroxasulfone } \\
+ \text { metribuzin }\end{array}$ & $98 a$ & $98 a$ & $93 a b$ & $95 a b$ & $96 a$ & $87 c$ & $92 a$ & $83 c$ & $88 b$ \\
\hline $\begin{array}{l}\text { Chlorimuron/ } \\
\text { flumioxazin/ metribuzin }\end{array}$ & $98 a$ & $96 a b$ & $85 a b$ & $96 a b$ & $94 a$ & $92 a b$ & $93 a$ & $84 c$ & $83 c$ \\
\hline $\begin{array}{l}\text { Imazethapyr/ } \\
\text { pyroxasulfone/saflufenacil }\end{array}$ & $82 b$ & $96 a b$ & $59 b c$ & $92 b$ & $70 b$ & $94 a$ & $73 b$ & $88 b$ & $77 d$ \\
\hline$p$-value & $<.001$ & $<.001$ & $<.001$ & $<.001$ & .041 & .009 & $<.001$ & .001 & $<.001$ \\
\hline Site-years ( $n$ ) & $6(672)$ & 7 (784) & $5(560)$ & $5(560)$ & $4(448)$ & $6(672)$ & $4(448)$ & $7(784)$ & $6(672)$ \\
\hline
\end{tabular}

Note. Weed control data at 14 and 28 DAPRE were combined for all study locations in 2018 and 2019. Data were $\log (x+1)$ or square root transformed before analysis; however back transformed values are presented based on interpretations of transformed data. Mean separation for weed control at 14 and 28 DAPRE excluded comparisons to the nontreated control and weed-free control, whereas biomass reduction at 28-45 DAPRE included the comparison of PRE herbicide programs to the nontreated control and weed-free control.

a. PRE, pre-emergence.

b. Total weed biomass in the nontreated control at 28-45 DAPRE was $258 \mathrm{~g} \mathrm{~m}^{-2}$.

c. Means presented within the same column with no common letters are significantly different according to estimated marginal means with Sidak confidence-level adjustments and Tukey $P$ value adjustments. 
Table 4 Weed density at 14 and 28 days after ore-emergence herbicide application (DAPRE) in field experiments conducted across five locations in Nebraska to determine economics of herbicide programs in conventional, glufosinate, and dicamba/ glyphosate-resistant soybean in 2018 and 2019.

\begin{tabular}{|c|c|c|c|c|c|c|c|c|c|}
\hline \multirow[b]{2}{*}{ Herbicide program ${ }^{a}$} & \multicolumn{2}{|c|}{$\begin{array}{l}\text { Palmer } \\
\text { amaranth }\end{array}$} & \multicolumn{2}{|c|}{$\begin{array}{l}\text { Common } \\
\text { lambsquarters }\end{array}$} & \multicolumn{2}{|c|}{ Velvetleaf } & \multicolumn{2}{|c|}{ Grass species } & \multirow{2}{*}{$\begin{array}{l}\begin{array}{l}\text { Total } \\
\text { density }\end{array} \\
\text { reduction }\end{array}$} \\
\hline & $\begin{array}{l}14 \\
D A P R E\end{array}$ & $\begin{array}{l}28 \\
D A P R E\end{array}$ & $\begin{array}{l}14 \\
D A P R E\end{array}$ & $\begin{array}{l}28 \\
D A P R E\end{array}$ & $\begin{array}{l}14 \\
D A P R E\end{array}$ & $\begin{array}{l}28 \\
D A P R E\end{array}$ & $\begin{array}{l}14 \\
D A P R E\end{array}$ & $\begin{array}{l}28 \\
D A P R E\end{array}$ & \\
\hline & & & & no. plant & $m^{-2}$ & & 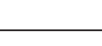 & - & $\%$ \\
\hline Nontreated control & $5 c$ & $30 c$ & $21 d$ & $44 c$ & $5 b$ & $8 c$ & $16 b$ & $18 c$ & Oe \\
\hline Weed-free control & $0 \mathrm{a}$ & $0 a$ & $0 a$ & $0 \mathrm{a}$ & $0 a$ & $0 \mathrm{a}$ & $0 \mathrm{a}$ & Oa & $100 a$ \\
\hline $\begin{array}{l}\text { Sulfentrazone/ } \\
\text { S-metolachlor } \\
\text { + metribuzin }\end{array}$ & Oa & $1 a b$ & $0 a$ & $1 a$ & $1 a$ & $2 b$ & $1 \mathrm{a}$ & Oa & $79 b$ \\
\hline $\begin{array}{l}\text { Chlorimuron/ } \\
\text { flumioxazin/ } \\
\text { thifensulfuronmethyl }\end{array}$ & Oa & $2 b$ & $4 c$ & $13 b$ & Oa & $1 a b$ & $4 a$ & $3 b$ & $61 d$ \\
\hline $\begin{array}{l}\text { Flumioxazin/ } \\
\text { pyroxasulfone+ } \\
\text { metribuzin }\end{array}$ & $0 \mathrm{a}$ & $1 a b$ & $0 a$ & $6 a b$ & $0 a$ & $1 a b$ & $2 a$ & $1 a b$ & $73 b c$ \\
\hline $\begin{array}{l}\text { Chlorimuron/ } \\
\text { flumioxazin/ } \\
\text { metribuzin }\end{array}$ & Oa & $1 a b$ & $1 a b$ & $8 b$ & $0 a$ & $1 a b$ & Oa & $1 a b$ & $71 b c$ \\
\hline $\begin{array}{l}\text { Imazethapyr/ } \\
\text { pyroxasulfone/ } \\
\text { saflufenacil }\end{array}$ & $1 \mathrm{a}$ & $1 a b$ & $3 b c$ & $11 b$ & $1 \mathrm{a}$ & $0 a$ & $2 a$ & Oa & $68 c d$ \\
\hline$P$-value & $<.001$ & $<.001$ & $<.001$ & $<.001$ & $<.001$ & $<.001$ & $<.001$ & $<.001$ & $<.001$ \\
\hline Site-years (n) & $5(560)$ & $7(784)$ & $5(560)$ & $6(672)$ & $4(448)$ & $6(672)$ & $5(560)$ & 7 (784) & $8(896)$ \\
\hline
\end{tabular}

Note. Weed density data at 14 and 28 DAPRE were combined for all study locations in 2018 and 2019. Data were $\log (x+1)$ or square-root transformed before analysis; however, back-transformed values are presented based on interpretations of transformed data. Mean separation for weed density at 14 and 28 DAPRE and total density reduction at 28 DAPRE included comparisons of PRE herbicide programs to the nontreated control and weed-free control.

a. PRE, pre-emergence.

b. Total weed density in the nontreated control at 28-45 DAPRE was 160 plants $\mathrm{m}^{-2}$.

c. Means within the same column with no common letters are significantly different according to estimated marginal means with Sidak confidence-level adjustments and Tukey $P$ value adjustments. 
Table 5 Weed control at 14 and 28 days after post-emergence herbicide application (DAPOST) in field experiments conducted across five locations in Nebraska to determine economics of herbicide programs in conventional, glufosinate, and dicamba/ glyphosate-resistant soybean in 2018 and 2019

\begin{tabular}{|c|c|c|c|c|c|c|c|c|c|}
\hline \multirow[b]{3}{*}{ Herbicide program ${ }^{a}$} & \multicolumn{2}{|c|}{$\begin{array}{l}\text { Palmer } \\
\text { amaranth }\end{array}$} & \multicolumn{2}{|c|}{$\begin{array}{l}\text { Common } \\
\text { lambsquarters }\end{array}$} & \multicolumn{2}{|c|}{ Velvetleaf } & \multicolumn{2}{|c|}{ Grass species } & \multirow{3}{*}{$\begin{array}{l}\begin{array}{l}\text { Total } \\
\text { biomass } \\
\text { reductiont }\end{array} \\
28-45 \\
\text { DAPRE }\end{array}$} \\
\hline & 14 & 28 & 14 & 28 & 14 & 28 & 14 & 28 & \\
\hline & $D A P R E$ & DAPRE & $D A P R E$ & DAPRE & $D A P R E$ & $D A P R E$ & DAPRE & $D A P R E$ & \\
\hline Nontreated control & 0 & 0 & 0 & 0 & 0 & 0 & 0 & 0 & 0 \\
\hline Weed-free control & 99 & 99 & 99 & 99 & 99 & 99 & 99 & 99 & 100 \\
\hline Dicamba + glyphosate & 97 & 95 & $98 a$ & $98 a$ & $98 a$ & $98 a$ & 97 & 98 & $98 a$ \\
\hline Glyphosate & 94 & 93 & $98 a$ & $98 a$ & $98 a$ & $98 a$ & 98 & 97 & $97 a$ \\
\hline Glufosinate & 96 & 94 & $98 a$ & $97 a$ & $98 a$ & $97 a$ & 97 & 97 & $97 a$ \\
\hline $\begin{array}{l}\text { Acetochlor + } \\
\text { clethodim + } \\
\text { lactofen }\end{array}$ & 95 & 94 & $90 \mathrm{~b}$ & $87 b$ & $90 \mathrm{~b}$ & $89 b$ & 94 & 95 & $89 b$ \\
\hline POST $P$-value & .631 & .216 & .008 & .024 & .001 & $<.001$ & .128 & .501 & $<.001$ \\
\hline PRE $P$-value & .999 & .150 & .999 & .957 & .999 & .999 & .986 & .994 & .896 \\
\hline Site-years ( $n)$ & 7 (784) & $7(784)$ & $5(560)$ & $5(560)$ & $4(448)$ & $4(448)$ & $7(784)$ & 7 (784) & $7(784)$ \\
\hline
\end{tabular}

Note. Weed control data at 14 and 28 DAPOST were combined for all study locations in 2018 and 2019. Data were log $(x+1)$ or square root transformed before analysis; however, back-transformed values are presented based on interpretations of transformed data. Mean separation for weed control at 14 and 28 DAPOST and weed biomass reduction at 28 DAPOST excluded comparisons to the nontreated control and weed-free control.

a. PRE, pre-emergence; POST, postemergence.

b. Total weed biomass for the nontreated control at 28 DAPOST was $1,178 \mathrm{~g} \mathrm{~m}^{-2}$.

c. Means presented within the same column with no common letters are significantly different according to estimated marginal means with Sidak confidence-level adjustments and Tukey $P$ value adjustments. 
Table 6 Weed density at 14 and 28 days after POST herbicide application (DAPOST) in field experiments conducted across five locations in Nebraska to determine economics of herbicide programs in conventional, glufosinate, and dicamba/ glyphosate-resistant soybean in 2018 and 2019.

\begin{tabular}{|c|c|c|c|c|c|c|c|c|c|}
\hline \multirow[b]{3}{*}{ Herbicide program ${ }^{a}$} & \multicolumn{2}{|c|}{$\begin{array}{l}\text { Palmer } \\
\text { amaranth }\end{array}$} & \multicolumn{2}{|c|}{$\begin{array}{l}\text { Common } \\
\text { lambsquarters }\end{array}$} & \multicolumn{2}{|c|}{ Velvetleaf } & \multicolumn{2}{|c|}{ Grass species } & \multirow{3}{*}{$\begin{array}{l}\text { Total } \\
\text { density } \\
\text { reduction }\end{array}$} \\
\hline & 14 & 28 & 14 & 28 & 14 & 28 & 14 & 28 & \\
\hline & $D A P R E$ & $D A P R E$ & DAPRE & $D A P R E$ & $D A P R E$ & $D A P R E$ & $D A P R E$ & $D A P R E$ & \\
\hline & & & & \multicolumn{2}{|c|}{ - no. plants $m^{2}$} & & & & $\%$ \\
\hline Nontreated control & 9 & 11 & 24 & 18 & 4 & 7 & 13 & 34 & 0 \\
\hline Weed-free control & 0 & 0 & 0 & 0 & 0 & 0 & 0 & 0 & 100 \\
\hline Dicamba + glyphosate & 0 & 1 & Oac & 0 & Oa & $0 a$ & Oa & 0 & 94 \\
\hline Glyphosate & 1 & 1 & Oa & 0 & 0a & Oa & 0a & 0 & 94 \\
\hline Glufosinate & 1 & 1 & Oa & 0 & 0a & $0 a$ & Oa & 1 & 92 \\
\hline $\begin{array}{l}\text { Acetochlor + } \\
\text { clethodim + } \\
\text { lactofen }\end{array}$ & 0 & 1 & $1 b$ & 2 & $1 b$ & $1 b$ & $1 b$ & 2 & 86 \\
\hline POST $P$-value & .369 & .633 & .016 & .999 & $<.001$ & $<.001$ & .007 & .999 & .832 \\
\hline PRE $P$-value & .930 & .651 & .973 & .999 & .998 & .997 & .543 & .999 & .949 \\
\hline Site-years (n) & $6(672)$ & 7 (784) & $5(560)$ & 7 (784) & $4(448)$ & $4(448)$ & $6(672)$ & 7 (784) & 7 (784) \\
\hline
\end{tabular}

Note. Weed density data at 14 and 28 DAPOST were combined for all study locations in 2018 and 2019. Data were log $(x+1)$ or square root transformed before analysis; however, back-transformed values are presented based on interpretations of transformed data. Mean separation for weed density at 14 and 28 DAPOST and total density reduction excluded comparisons to the nontreated control and weed-free control.

a. PRE, pre-emergence; POST, post-emergence.

b. Total weed density in the nontreated control at 28 DAPOST was 85 plants $\mathrm{m}^{-2}$.

c. Means within the same column with no common letters are significantly different according to estimated marginal means with Sidak confidence-level adjustments and Tukey $P$ value adjustments. 


\subsection{Soybean injury}

Pre-emergence herbicide programs evaluated in this study displayed a high margin of crop safety, with $\leq 4 \%$ soybean injury at 14 or 28 DAPRE across site-years (Supplemental Table 1).No crop injury was observed in DGR soybean at 14 or 28 DAPOST, whereas off-target movement of dicamba in GLU-R and conventional soybean resulted in phytotoxic deformities of $12-13 \%$ at 14 DAPOST and $11-12 \%$ at 28 DAPOST (Supplemental Table 2). Across all site-years, crop injury from dicamba in dicamba-sensitive cultivars did not exceed the threshold of $30 \%$ injury required to cause greater than $5 \%$ soybean yield loss, as reported in a meta-analysis conducted by Kniss (2018). Lactofen applied POST in conventional soybean resulted in 12 and $9 \%$ phytotoxic necrosis at 14 and 28 DAPOST, with lactofen injury fading as the growing season progressed. It has been previously reported that crop injury from lactofen does not usually result in yield loss (Sarangi et al., 2015; Wichert \& Talbert, 1993).

\subsection{Soybean yield}

For individual site-years presented in this study, the main effect of PRE herbicide program was significant for six of six site-years, whereas the main effect of POST herbicide program was significant for four of six site-years (data not shown). Due to a significant site-year effect $(P=.002)$, locations were analyzed by site-years. The interaction of PRE by POST herbicide program was significant at all study locations (Table 7), excluding North Platte in 2019 ( $P=.132$ ); therefore, analyses of soybean yield and economics were conducted on PRE fb POST herbicide programs. Across site-years, soybean yield for PRE fb POST herbicide programs in DGR, GLU-R, and conventional soybean was similar to the weed-free control for the respective system for nearly all PRE fb POST programs. At Clay Center, conventional soybean receiving chlorimuron/flumioxazin/thifensulfuron or imazethapyr/pyroxasulfone/saflufenacil produced 2,000-2,360 $\mathrm{kg} \mathrm{ha}^{-1}$ less than the weed-free control $\left(3,771 \mathrm{~kg} \mathrm{ha}^{-1}\right)$ in 2019 (Table 7). Conventional soybean yield was similar to HR cultivars for all PRE fb POST herbicide programs at Lincoln in 2018 and Concord in 2019. In contrast, conventional soybean yield was significantly lower than HR cultivars at Clay Center, 


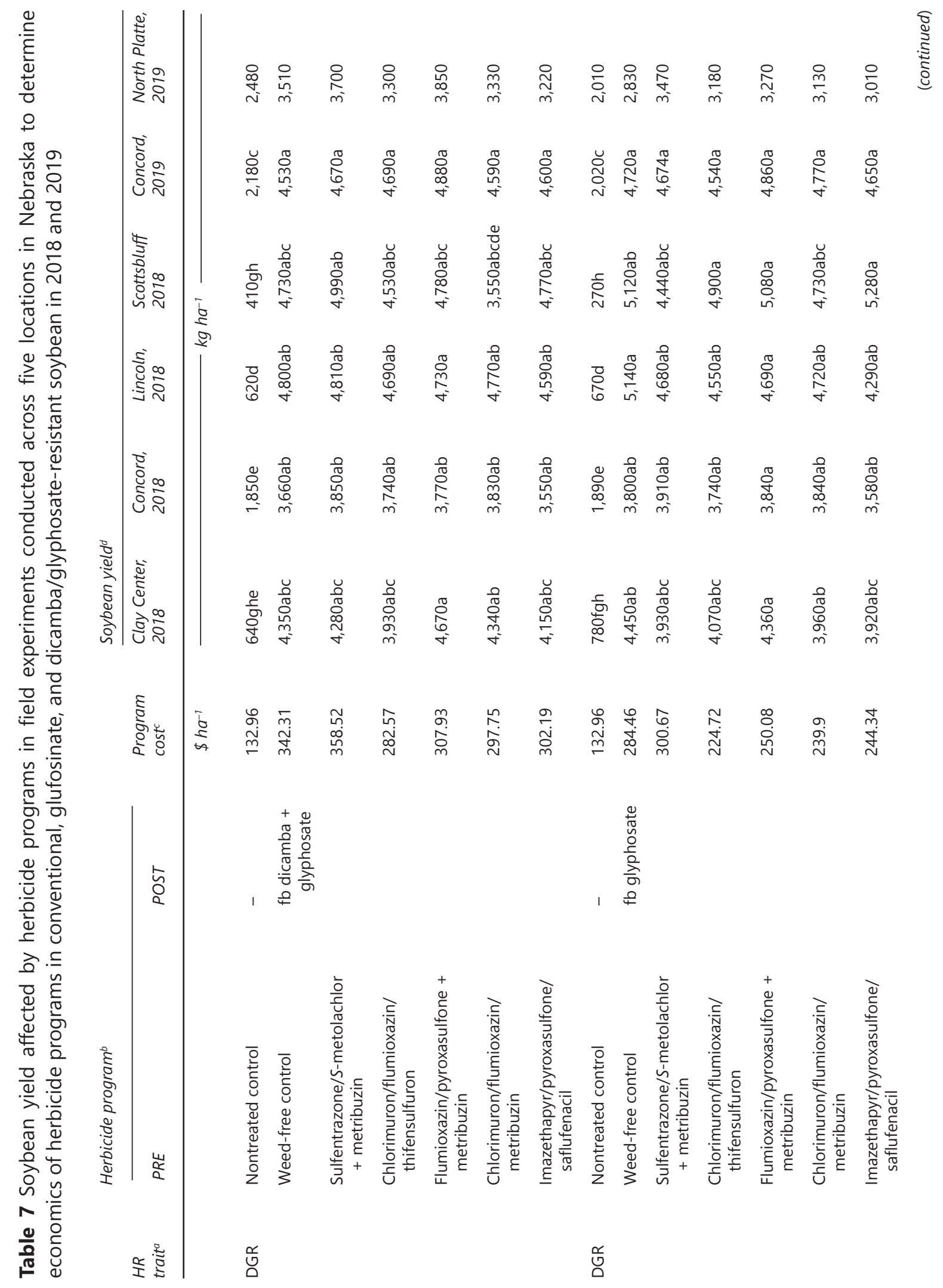




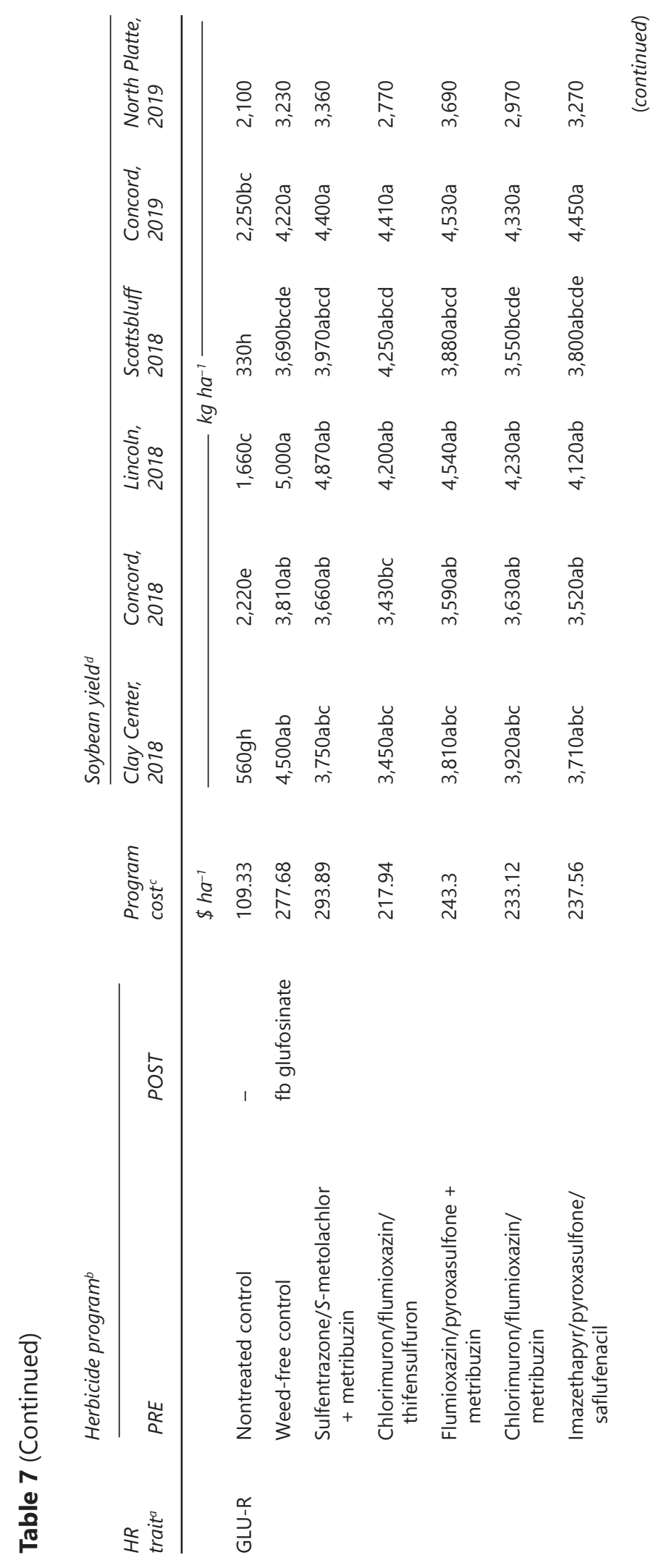




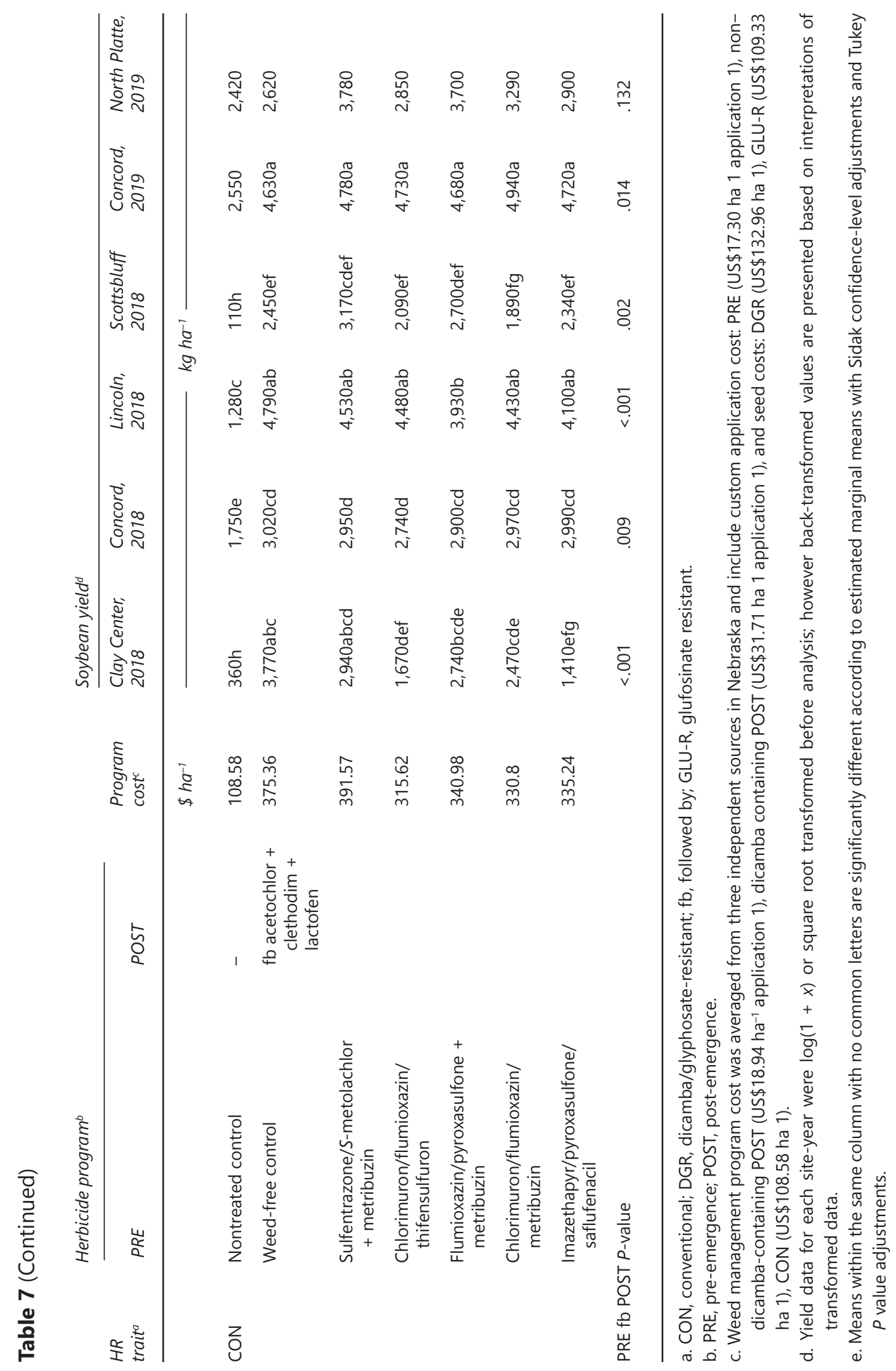


Concord, and Scottsbluff in 2018 (Table 7), although poor field emergence of conventional soybean cultivar U11-917032 (95,000 plants ha $^{-1}$ ) at Scottsbluff in 2018 likely contributed to the reduced yield potential for that specific site-year. Soybean yield in GLU-R soybean was similar to DGR soybean for all site-years (Table 7).

\subsection{Economic analysis}

Pre-emergence herbicide program plus cost of custom application ranged from US $\$ 58.30$ to US $\$ 135.25 \mathrm{ha}^{-1}$, whereas POST herbicide programs plus cost of custom application ranged from US $\$ 33.46$ to US $\$ 148.74$ ha $^{-1}$ (Table 2). Herbicide program costs were added to the cost of conventional and HR cultivar seed, with the weighted average of US $\$ 132.96 \mathrm{ha}^{-1}$ for DGR soybean, US $\$ 109.33 \mathrm{ha}^{-1}$ for GLU-R soybean, and US $\$ 108.58 \mathrm{ha}^{-1}$ for commercially available conventional soybean cultivars across all locations (Table 8). Low local demand at most locations for conventional soybean seed resulted in higher-than expected conventional seed costs.

Gross profit margins for most weed management programs in DGR cultivars were similar within most site-years, with a study-wide average gross profit margin of US $\$ 976.56$ and US $\$ 1023.56 \mathrm{ha}^{-1}$ for dicamba/glyphosate and glyphosate, respectively (Table 8). In GLU-R cultivars, gross profit margin was comparable to DGR cultivars with a study-wide average of US\$928.24 ha-1 (Table 8), whereas in conventional weed management programs, gross profit margins were lower than in HR cultivars, with a study-wide average of US $\$ 722.02 \mathrm{ha}^{-1}$ for grain marketed without price premiums (data not shown). However, the lower gross profit margins in conventional soybean could be partially compensated by including a price premium for non-GM soybean, with a study-wide average of US $\$ 814.12 \mathrm{ha}^{-1}$ for grain marketed with a $\$ 0.05 \mathrm{~kg}^{-1}$ price premium (Table 8). At Lincoln and Scottsbluff in 2018 and 2019, gross profit margins for conventional soybean marketed with a price premium were similar or exceeded the gross profit margin for many HR soybean programs.

Benefit/cost ratios in this study varied by both site-year and soybean cultivar. In HR and conventional soybean, PRE fb POST herbicide provided similar or greater benefit/cost ratios to the weed-free control for most site-years (Table 9). Across all site-years excluding North Platte 


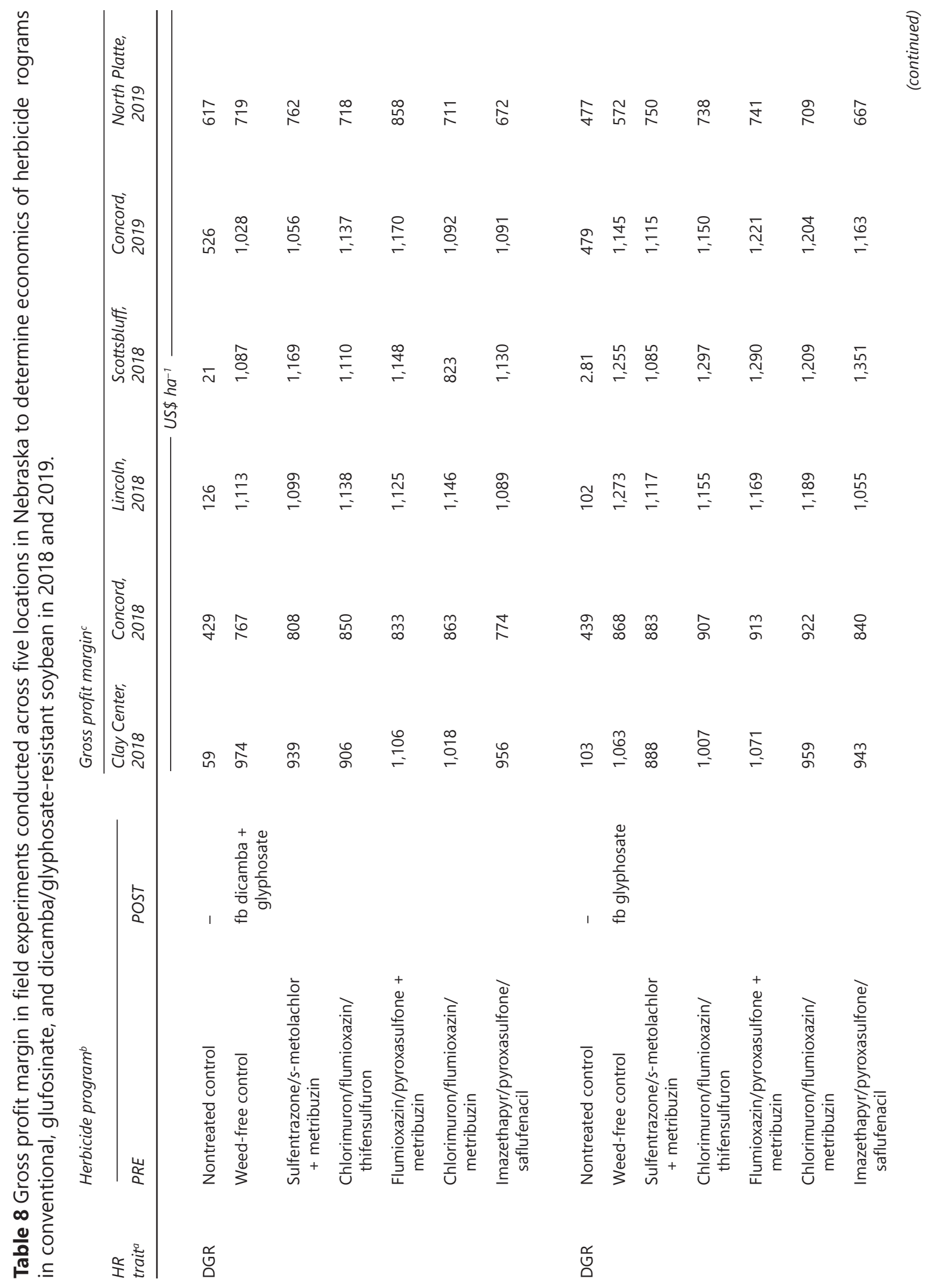




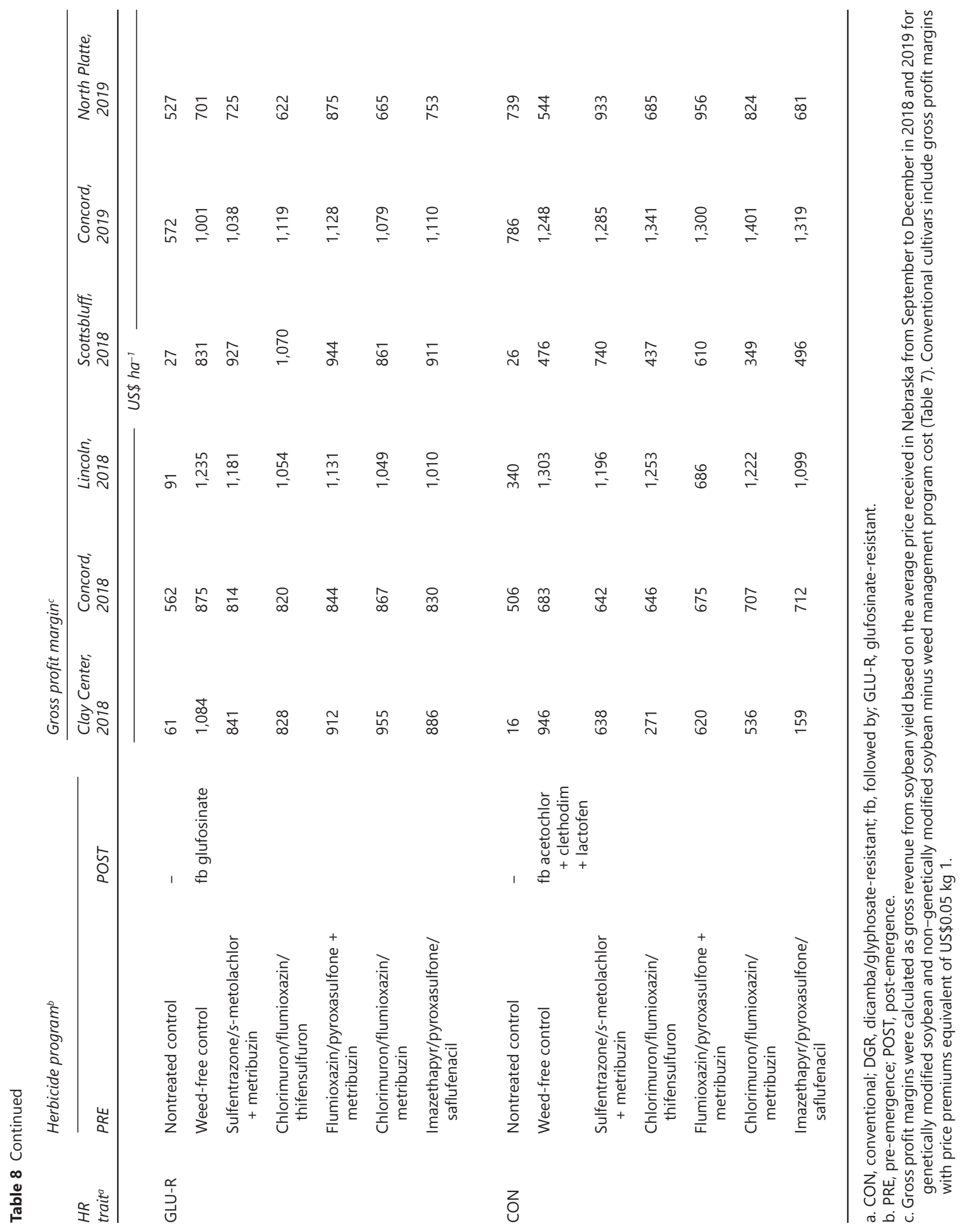




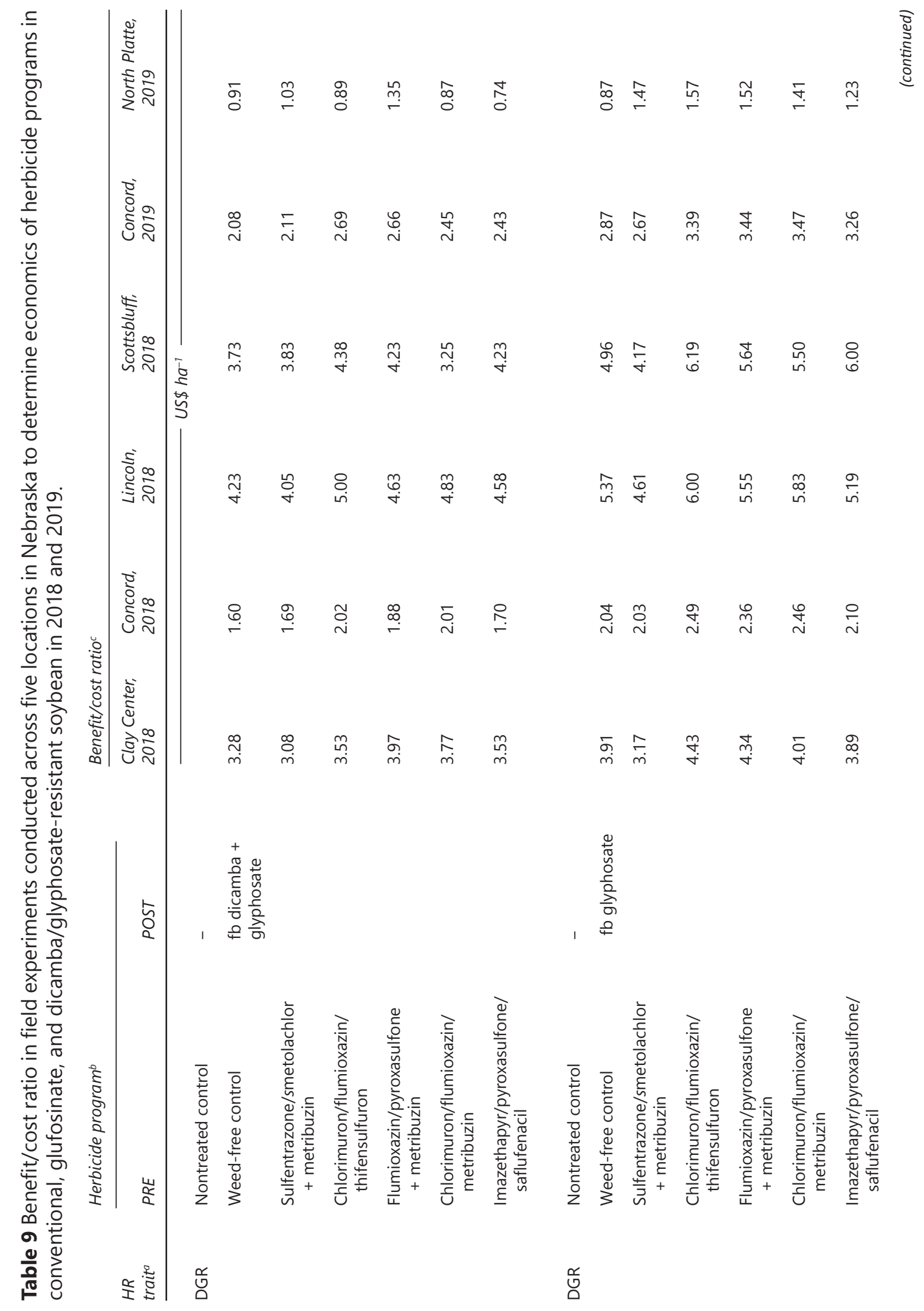




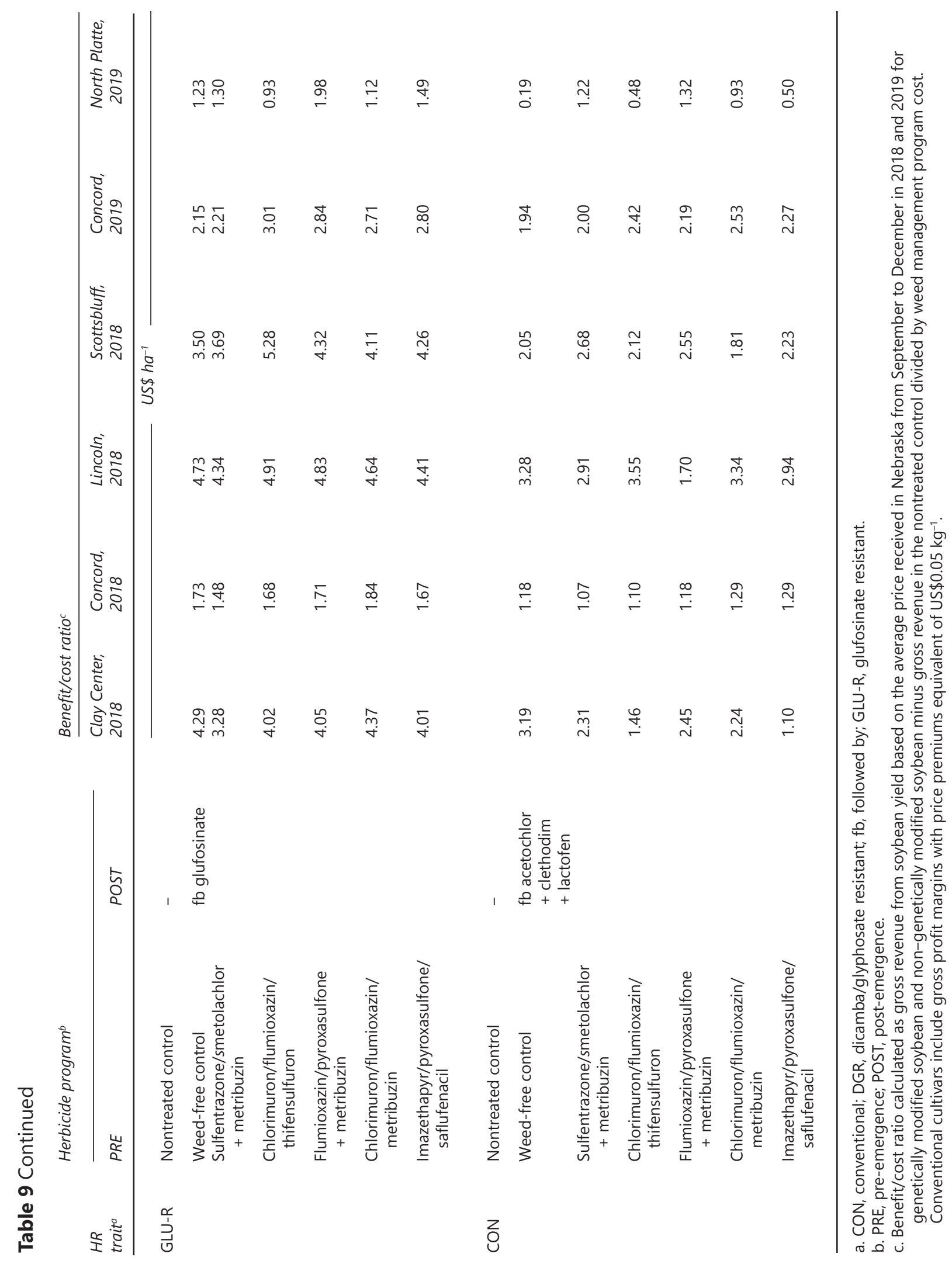


in 2019, study-wide averages for DGR soybean receiving dicamba plus glyphosate or glyphosate was 3.64 and 4.42, respectively. In GLU-R soybean, the average benefit/cost ratio was 3.91, whereas in conventional soybean the average benefit/cost ratio was 2.25 . The benefit/cost ratio for PRE fb POST herbicide programs was reduced to $<2.0$ at North Platte in 2019, primarily due to late-season competition with kochia (data not shown).

\section{Discussion}

Results of this study support the recommendation of using PRE herbicide with multiple effective SOA in DGR, GLU-R, and conventional soybean and are consistent with the scientific literature for control of broadleaf and grass weed species evaluated. It has been reported that sulfentrazone/metribuzin provided 92-99\% control of common lambsquarters, waterhemp, and velvetleaf 15 DAPRE and 98\% control of Palmer amaranth 28 DAPRE in Nebraska (Aulakh \& Jhala, 2015; Sarangi \& Jhala, 2019). Similarly, Belfry, Cowbrough, Tardif, and Sikkema (2016) reported that $S$-metolachlor plus metribuzin provided $92-100 \%$ control of common ragweed, green foxtail, and common lambsquarters 14 DAPRE. Sarangi et al. (2017) reported chlorimuron/flumioxazin/thifensulfuron provided 88\% control of GR waterhemp 21 DAPRE in GR soybean in Nebraska. Likewise, Soltani, Nurse, and Sikkema (2014) and Hedges, Hooker, Robinson, \& Sikkema (2019) reported that flumioxazin/pyroxasulfone provided 97-99\% control of velvetleaf, common ragweed, common lambsquarters, waterhemp, and green foxtail 28 DAPRE. Hay, Shoup, and Peterson (2019) reported that flumioxazin/pyroxasulfone and chlorimuron/ flumioxazin/metribuzin tank-mixed with paraquat provided 90 and 93\% control of Palmer amaranth 56 DAPRE, respectively, in field experiments conducted in Kansas. Similarly, Sarangi and Jhala (2019) reported that chlorimuron/flumioxazin/metribuzin provided 96\% control of velvetleaf 28 DAPRE in field experiments conducted in Nebraska. The efficacy of various soybean herbicide pre-mixes tank-mixed with glyphosate have been studied in four 2-yr studies in Ontario, Canada, where imazethapyr/saflufenacil plus glyphosate provided 60-83\% control of common ragweed $56 \mathrm{~d}$ after application, with 79-82\% biomass reduction (Wely et al., 2014). Likewise, pyroxasulfone 
applied alone at $150 \mathrm{~g}$ ai ha ${ }^{-1}$ provided 94\% control of GR waterhemp at 28 DAPRE (Hedges, Soltani, Hooker, Robinson, \& Sikkema, 2019) and 95\% control of GR waterhemp at 21 DAPRE applied at $208 \mathrm{~g}$ ai ha-1 (Sarangi et al., 2017).

From a weed management standpoint, POST herbicide programs in HR soybean provided 94-99\% control of Palmer amaranth, common lambsquarters, velvetleaf, and grass weed species. Competition from GR weeds in glyphosate applied POST programs was expected due to their prevalence in Nebraska (Sarangi \& Jhala, 2018); however, due to the relatively low frequency of GR weed species at study locations in 2018 and 2019, this was not observed in current study. Multiple herbicide-resistant soybeans, such as isoxaflutole/glufosinate/glyphosate-resistant soybean (LibertyLink/GT27) and dicamba/glufosinate/ glyphosate-resistant soybean (XtendFlex), will be available commercially in the near future (Beckie et al., 2019). Therefore, glufosinate remains a viable POST herbicide option for control of GR weeds (Barnes et al., 2017; Jhala et al., 2017). In conventional soybean, a POST program of clethodim plus lactofen including an overlapping residual of acetochlor provided 87-95\% control of broadleaf and grass weeds. Producers interested in conventional soybean should take special care to select fields with a weed spectrum that can be managed effectively with PRE fb POST herbicide applications of acetolactate synthase and PPO-inhibiting herbicides along with residual activity of long chain fatty acid inhibitors, such as acetochlor/ $S$-metolachlor/ pyroxasulfone, because POST herbicides such as 2,4-D, dicamba, glyphosate, or glufosinate cannot be used as a "rescue treatment." The total cost of PRE herbicide programs examined in this study was within $\$ 10 \mathrm{ha}^{-1}$, excluding chlorimuron/ flumioxazin/thifensulfuron, which was US $\$ 15$ to US\$20 ha h $^{-1}$ less expensive, and sulfentrazone $/ S$-metolachlor plus metribuzin (US\$134.25 ha-1), which was substantially more expensive due to the application of metribuzin at a full-labeled rate for medium-textured soils with $2-4 \%$ organic matter (700 g ai ha ${ }^{-1}$ ). Previous research with metribuzin tank-mixed with other herbicides has shown that this rate could have been reduced without compromising weed control efficacy and soybean yield potential (Hedges et al., 2019; Kaur, Sandell, Lindquist, \& Jhala, 2014; Sarangi \& Jhala, 2019; Underwood et al., 2016; Wely et al., 2014; Whitaker, York, Jordan, \& Culpepper, 2010). 
Total cost of POST herbicide programs varied by soybean system. The least expensive POST herbicide programs were glyphosate or glufosinate. The conventional POST herbicide program was the most expensive (US\$148.74 ha-1) primarily because it included lactofen for waterhemp and Palmer amaranth control and acetochlor to provide an overlapping residual activity to address concerns with late-season weed emergence and weed control issues as reported in the literature (Rosenbaum et al., 2013; Sarangi \& Jhala, 2019). Sarangi and Jhala (2019) reported that the use of overlapping residual herbicides was effective for providing season-long control of Palmer amaranth and velvetleaf in conventional soybean in Nebraska. In the same study, it was reported that lactofen applied POST at $210 \mathrm{~g}$ ai ha ${ }^{-1}$ alone or tank-mixed with other herbicides provided 91\% control of GR waterhemp 28 DAPOST.

Reduced grain production rates by conventional soybean observed in the current study at three locations agree with results of a five-location, 2-yr study reported by Owen et al. (2010) in which conventional soybean cultivars produced 265 and $315 \mathrm{~kg} \mathrm{ha}^{-1}$ less yield than GR and GLUR cultivars, respectively. Likewise, Werle, Glewen, et al. (2018) reported that conventional soybean produced $202 \mathrm{~kg} \mathrm{ha}^{-1}$ less than GR and DGR soybean despite receiving the same conventional PRE fb POST herbicide program. However, although conventional soybean produced lower grain yields than HR soybean at three locations, grain yield was similar at Lincoln in 2018 and at Concord in 2019. These results are similar to a 3-yr, single-location study conducted in Tennessee that reported similar crop yields for GR and conventional soybean (Gaban, 2013). Similar yield potential and weed control in conventional, GR, and GLU-R soybean cultivars were also reported by Culpepper, York, Batts, and Jennings (2000) in a 3-yr, six-location study in North Carolina. With variable results in the literature, yield potential of conventional cultivars compared with HR cultivars is inconclusive, as is the underlying cause for these reported yield differences or lack thereof. Differences in genetic yield potential, herbicide injury, and increased competition with weeds are all plausible factors that could result in reduced soybean grain yield in conventional cultivars. Results from the current study support conventional soybean can produce similar yield to HR soybean in some locations, which is likely due in part to differences in location-specific weed spectrum and weed pressure. Results from this study also indicated that soybean yield in GLU-R soybean was similar to DGR soybean. 
The higher gross profit margin observed with HR soybean cultivars was due primarily to increased herbicide costs in conventional soybean and reduced yield in certain site-years. In this study, POST herbicide program in conventional soybean included acetochlor as an overlapping residual herbicide, which was not present in POST herbicide programs in HR soybean systems. This additional input added to the cost of the conventional soybean system. However, in site-years where conventional soybean produced similar crop yield to HR soybean, gross profit margins were similar or slightly higher when a $\$ 0.05 \mathrm{~kg}^{-1}$ price premium for non-GM soybean was included. These results indicate that price premiums for non-GM soybean can either partially or fully compensate for additional herbicide costs in conventional programs; however, after including price premium, study-wide gross profit margins were on average US\$114 to US\$209 ha-1 lower in conventional soybean compared with DGR and GLU-R soybean. Results of the current study also indicate that GLU-R soybean can provide similar economic return as DGR soybean.

Potential price savings for PRE fb POST herbicide programs evaluated in this study are possible, with herbicide rebate programs, generic formulations of specific active ingredients or pre-mixture product, and alternative products being commercially available to soybean producers. Special care should be taken when selecting herbicides for weed management in conventional or HR soybean to ensure the products provide multiple effective SOA for control of HR weeds and adequately address the weed spectrum for the specific location.

\section{$\Delta \Delta \Delta \nabla$}

Acknowledgments The authors thank Irvin Schleufer, Jeff Golus, Dr. Jon Scott, Mike Schlick, and Whitney Schultz for help at their respective study locations. The authors acknowledge current and previous graduate and undergraduate students Adam Leise, Dr. Bruno Vieira, Clint Beiermann, Debora Latorre, Dr. Ethann Barnes, Jesaelen Moraes, Jared Stander, Jasmine Mausbach, Josh Wehrbein, Kaity Wilmes, Kolby Grint, Mary Happ, Milos Zaric, Dr. Parminder Chahal, Shawn McDonald, Dr. Tommy Butts, and Will Neels for assistance with field work. This project was supported by Nebraska Soybean Board proposal \#1733.

Funding information Nebraska Soybean Board, Grant/Award Number: 1733

Conflicts of interest The authors declare no conflicts of interest. 


\section{References}

Anonymous. (2020). Dicamba-, glyphosate- and glufosinate-resistant soybeans | clean fields and high yield potential. Retrieved from https://www. roundupreadyxtend.com/products/Pages/soybeans.aspx

Aulakh, J. S., \& Jhala, A. J. (2015). Comparison of glufosinate-based herbicide programs for broad-spectrum weed control in glufosinate-resistant soybean. Weed Technology, 29, 419-430. https://doi.org/10.1614/WT-D-15-00014.1

Barnes, E. R., Knezevic, S. Z., Sikkema, P. H., Lindquist, J. L., \& Jhala, A. J. (2017). Control of glyphosate-resistant common ragweed (Ambrosia artemisiifolia L.) in glufosinate-resistant soybean [Glycine max (L.) merr]. Frontiers in Plant Science, 8, 1455. https://doi.org/10.3389/fpls.2017.01455

Bates, D., Machler, M., Bolker, B., \& Walker, S. (2015). Fitting linear mixed-effects models using lme4. Journal of Statistical Software, 67, 1-48. https://doi. org/10.18637/jss.v067.i01

Beckie, H. J., Ashworth, M. B., \& Flower, K. C. (2019). Herbicide resistance management: Recent developments and trends. Plants, 8, 161. https://doi. org/10.3390/plants8060161

Beckie, H. J., \& Harker, K. N. (2017). Our top 10 herbicide-resistant weed management practices. Pest Management Science, 73, 1045- 1052. https://doi. org/10.1002/ps.4543

Beckie, H. J., \& Reboud, X. (2009). Selecting for weed resistance: Herbicide rotation and mixture. Weed Technology, 23, 363-370. https://doi.org/10.1614/ WT-09-008.1

Belfry, K. D., Cowbrough, M. J., Tardif, F. J., \& Sikkema, P. H. (2016). Weed management options for conventional soybean. Canadian Journal of Plant Science, 96, 743747. https://doi.org/10.1139/cjps-2015-0353

Brooks, M. E., Kristensen, K., van Benthem, K. J., Magnusson, A., Berg, C. W., Nielsen, A., ... Bolker, B. M. (2017). GlmmTMB balances speed and flexibility among packages for zero-inflated generalized linear mixed modeling. The R Journal, 9, 378-400.

Busi, R., Powles, S. B., Beckie, H. J., \& Renton, M. (2019). Rotations and mixtures of soil-applied herbicides delay resistance. Pest Management Science, 76, 487-496. https://doi.org/10.1002/ps.5534

Butts, T. R., Norsworthy, J. K., Kruger, G. R., Sandell, L. D., Young, B. G., Steckel, L. E., ... Davis, V. M. (2016). Management of pigweed (Amaranthus spp.) in glufosinateresistant soybean in the Midwest and Mid-South. Weed Technology, 30, 355-365. https://doi.org/10.1614/WT-D-15-00076.1

Byker, H. P., Van Wely, A. C., Jhala, A. J., Soltani, N., Robinson, D. E., Lawton, M. B., \& Sikkema, P. H. (2018). Preplant followed by postemergence herbicide programs and biologically effective rate of metribuzin for control of glyphosate-resistant common ragweed (Ambrosia artemisiifolia) in soybean. Canadian Journal of Plant Science, 98, 809-814. https://doi.org/10.1139/cjps-2017-0299 
Chahal, P. S., \& Jhala, A. J. (2019). Integrated management of glyphosate-resistant horseweed (Erigeron canadensis) with tillage and herbicides in soybean. Weed Technology, 33, 859-866. https://doi.org/10.1017/wet.2019.74

Culpepper, A. S., York, A. C., Batts, R. B., \& Jennings, K. M. (2000). Weed management in glufosinate- and glyphosate-resistant soybean (Glycine max). Weed Technology, 14, 77-88. https://doi.org/10.1614/0890-037X(2000)014[0077:WMIGAG]2.0 . $\mathrm{CO} ; 2$.

De Bruin, J. L., \& Pedersen, P. (2008). Soybean seed yield response to planting date and seeding rate in the upper Midwest. Agronomy Journal, 100, 696-703. https:// doi.org/10.2134/agronj2007.0115

Federer, W. T., \& King, F. (2006). Variations on split plot and split block experiment designs. Hoboken, NJ: John Wiley \& Sons

Fox, J., \& Weisberg, S. (2019). An R companion to applied regression (3rd ed.). Thousand Oaks, CA: Sage.

Gaban, B. L. (2013). Comparison of roundup ready and conventional soybean (Glycine max L.) weed control systems for optimizing yield and economic profitability (Master's thesis, University of Tennessee, Knoxville). Retrieved from https:// trace.tennessee.edu/utk gradthes/1619/

Gage, K. L., Krausz, R. F., \& Walters, S. A. (2019). Emerging challenges for weed management in herbicide-resistant crops. Agriculture, 9, 180. https://doi. org/10.3390/agriculture 9080180

Hay, M. M., Shoup, D. E., \& Peterson, D. E. (2019). Herbicide options for control of palmer amaranth (Amaranthus palmeri) and common waterhemp (Amaranthus rudis) in double-crop soybean. Weed Technology, 33, 106-114. https://doi. org/10.1017/wet.2018.86

Heap, I. (2020). The international survey of herbicide resistant weeds: Weeds resistant to EPSP synthase inhibitors. Retrieved from http://www.weedscience. org/Summary/MOA.aspx?MOAID $=12$

Hedges, B. K., Soltani, N., Hooker, D. C., Robinson, D. E., \& Sikkema, P. H. (2019). Control of glyphosate-resistant waterhemp with preemergence herbicides in glyphosate- and dicamba-resistant soybean. Canadian Journal of Plant Science, 99, 34-39. https://doi.org/10.1139/cjps-2018-0046

Hothorn, T., Bretz, F., \& Westfall, P. (2008). Simultaneous inference in general parametric models. Biometrical Journal, 50, 346-363.

Jhala, A. J., Sandell, L. D., Sarangi, D., Kruger, G. R., \& Knezevic, S. Z. (2017). Control of glyphosate-resistant common waterhemp (Amaranthus rudis) in glufosinateresistant soybean. Weed Technology, 31, 32-45. https://doi.org/10.1017/ wet.2016.8

Kaur, S., Sandell, L. D., Lindquist, J. L., \& Jhala, A. J. (2014). Glyphosate-resistant giant ragweed (Ambrosia trifida) control in glufosinate-resistant soybean. Weed Technology, 28, 569-577. https://doi.org/10.1614/WT-D-14-00009.1

Knezevic, Stevan Z., \& Cassman, K. G. (2003). Use of herbicide-tolerant crops as a component of an integrated weed management program. Crop Management, 2, 0. https://doi.org/10.1094/CM-2003-0317-01-MG 
Knezevic, Stevan Z., Evans, S. P., Blankenship, E. E., Van Acker, R. C., \& Lindquist, J. L. (2002). Critical period for weed control: The concept and data analysis. Weed Science, 50, 773-786. https://doi.org/10.1614/0043-745(2002)050[0773:CPFW CT]2.0.CO;2.

Knezevic, S. Z., Creech, C. F., Jhala, A. J., Klein, R. N., Kruger, G. R., Proctor, C. A., ... Lawrence, N. C. (2020). Guide for weed, disease, and insect management in Nebraska. Lincoln: University of Nebraska-Lincoln Extension.

Kniss, A. R. (2018). Soybean response to dicamba: A meta-analysis. Weed Technology, 32, 507-512. https://doi.org/10.1017/wet.2018.74

Kniss, A. R., \& Streibig, J. C. (2018). Statistical analysis of agricultural experiments using R. Retrieved from https://rstats4ag.org/

Lenth, R. (2019). Emmeans: Estimated marginal means, aka least squares means. Retrieved from https://cran.r-project.org/web/packages/emmeans/index.html

Norsworthy, J. K., Ward, S. M., Shaw, D. R., Llewellyn, R. S., Nichols, R. L., Webster, T. M., ... Barrett, M. (2012). Reducing the risks of herbicide resistance: Best management practices and recommendations. Weed Science, 60, 31-62. https:// doi.org/10.1614/WS-D-11-00155.1

Owen, M. D. K., Pedersen, P., De Bruin, J. L., Stuart, J., Lux, J., Franzenburg, D., \& Grossnickle, D. (2010). Comparisons of genetically modified and non-genetically modified soybean cultivars and weed management systems. Crop Science, 50, 2597-2604. https://doi.org/10.2135/cropsci2010.01.0035

Owen, Micheal D. K. (2016). Diverse approaches to herbicide-resistant weed management. Weed Science, 64, 570-584. https://doi.org/10.1614/ WS-D-15-00117.1

Peterson, D. E., Thompson, C., \& Minihan, C. L. (2017). Comparison of different weed control technology programs. Kansas Agricultural Experiment Station Research Reports, 3(6). https://doi.org/10.4148/2378-5977.7444

Peterson, M. A., Collavo, A., Ovejero, R., Shivrain, V., \& Walsh, M. J. (2018). The challenge of herbicide resistance around the world: A current summary: Herbicide resistance around the world. Pest Management Science, 74, 22462259. https://doi.org/10.1002/ps.4821

R Core Team. (2018). R: A language and environment for statistical computing. Vienna: R Foundation for Statistical Computing. Retrieved from https://www.Rproject.org/

Ritz, C., Kniss, A. R., \& Streibig, J. C. (2015). Research methods in weed science: Statistics. Weed Science, 63(SP1), 166-187. https://doi.org/10.1614/ WS-D-13-00159.1

Rosenbaum, K. K., Massey, R. E., \& Bradley, K. W. (2013). Comparison of weed control, yield, and net income in conventional, glyphosate-resistant, and glufosinateresistant soybean. Crop Management, 12(1), 1-9. https://doi.org/10.1094/ cm-2013-0028-rs

Sarangi, D., \& Jhala, A. J. (2018). A statewide survey of stakeholders to assess the problem weeds and weed management practices in Nebraska. Weed Technology, 32, 642-655. https://doi.org/10.1017/wet.2018.35 
Sarangi, D., \& Jhala, A. J. (2019). Palmer amaranth (Amaranthus palmeri) and velvetleaf (Abutilon theophrasti) control in no-tillage conventional (nongenetically engineered) soybean using overlapping residual herbicide programs. Weed Technology, 33, 95-105. https://doi.org/10.1017/wet.2018.78

Sarangi, D., Sandell, L. D., Knezevic, S. Z., Aulakh, J. S., Lindquist, J. L., Irmak, S., \& Jhala, A. J. (2015). Confirmation and control of glyphosate-resistant common waterhemp (Amaranthus rudis) in Nebraska. Weed Technology, 29, 82-92. https://doi.org/10.1614/WT-D-14-00090.1

Sarangi, D., Sandell, L. D., Kruger, G. R., Knezevic, S. Z., Irmak, S., \& Jhala, A. J. (2017). Comparison of herbicide programs for season-long control of glyphosateresistant common waterhemp (Amaranthus rudis) in soybean. Weed Technology, 31, 53-66. https://doi.org/10.1017/wet.2016.1

Sbatella, G. M., Adjesiwor, A. T., Kniss, A. R., Stahlman, P. W., Westra, P., Moechnig, M., \& Wilson, R. G. (2019). Herbicide options for glyphosate-resistant kochia (Bassia scoparia) management in the Great Plains. Weed Technology, 33, 658-663. https://doi.org/10.1017/wet.2019.48

Schultz, J. L., Myers, D. B., \& Bradley, K. W. (2015). Influence of soybean seeding rate, row spacing, and herbicide programs on the control of resistant waterhemp in glufosinate-resistant soybean. Weed Technology, 29, 169-176. https://doi. org/10.1614/WT-D-14-00071.1

Schwartz-Lazaro, L. M., Norsworthy, J. K., Scott, R. C., \&Barber, L. T. (2017). Resistance of two Arkansas Palmer amaranth populations to multiple herbicide sites of action. Crop Protection, 96, 158-163. https://doi.org/10.1016/j. cropro.2017.02.022

Soltani, N., Nurse, R. E., \& Sikkema, P. H. (2014). Two-pass weed management with preemergence and postemergence herbicides in glyphosate-resistant soybean. Agricultural Sciences, 5, 504-512. https://doi.org/10.4236/as.2014.56052

Specht, J. (2016). Soybean seeding rate tips. University of Nebraska- Lincoln Institute of Agriculture and Natural Resources. Retrieved from https:// cropwatch.unl.edu/2016/soybean-seeding-rate-tips Stroup, W. W. (2015). Rethinking the analysis of non-normal data in plant and soil science. Agronomy Journal, 107, 811-827. https://doi.org/10.2134/agronj2013.0342

Underwood, M. G., Soltani, N., Hooker, D. C., Robinson, D. E., Vink, J. P., Swanton, C. J., \& Sikkema, P. H. (2016). The addition of dicamba to post applications of quizalofop-p-ethyl or clethodim antagonizes volunteer glyphosate-resistant corn control in dicamba-resistant soybean. Weed Technology, 30, 639-647. https:// doi.org/10.1614/WT-D-16-00016.1

USDA-ERS (2018). Recent trends in GE adoption. Retrieved from https://www.ers. usda.gov/data-products/adoption-of-genetically-engineered-crops-in-the-us/ recent-trends-in-geadoption.aspx

USDA-NASS. (2019). Nebraska agricultural statistics 2018-2019. Retrieved from https://www.nass.usda.gov/Statistics by State/Nebraska/

USDA-AMS. (2020). National weekly non-GMO/GE grain report. Retrieved from https://www.ams.usda.gov/mnreports/gl gr112.txt 
Wang, Y., Rodriguez de Gil, P., Chen, Y.-H., Kromrey, J. D., Kim, E. S., Pham, T., ... Romano, J. L. (2017). Comparing the performance of approaches for testing the homogeneity of variance assumption in one-factor ANOVA models. Educational and Psychological Measurement, 77, 305-329. https://doi. org/10.1177/0013164416645162

Wely, A. C. V., Soltani, N., Robinson, D. E., Hooker, D. C., Lawton, M. B., \& Sikkema, P. H. (2014). Control of glyphosate and acetolactate synthase resistant common ragweed (Ambrosia artemisiifolia L.) in soybean (Glycine max L.) with preplant herbicides. American Journal of Plant Sciences, 5, 3934-3942. https://doi. org/10.4236/ajps.2014.526412

Werle, R., Glewen, K., Spicka, S., Arneson, N. J., Elmore, R., \& Proctor, C. A. (2018). Results from 2017 soybean study and insights for 2018 planting. University of Nebraska-Lincoln Institute of Agriculture and Natural Resources. Retrieved from https://cropwatch.unl.edu/2018/ results-2017-soybean-study-and-insights-2018-planting

Werle, R., Oliveira, M. C., Jhala, A. J., Proctor, C. A., Rees, J., \& Klein, R. (2018). Survey of Nebraska farmers' adoption of dicamba-resistant soybean technology and dicamba off-target movement. Weed Technology, 32, 754-761. https://doi. org/10.1017/wet.2018.62

Whitaker, J. R., York, A. C., Jordan, D. L., \& Culpepper, A. S. (2010). Palmer amaranth (Amaranthus palmeri) control in soybean with glyphosate and conventional herbicide systems. Weed Technology, 24, 403-410. https://doi.org/10.1614/ WT-D-09-00043.1

Wichert, R. A., \& Talbert, R. E. (1993). Soybean [Glycine max (L.)] response to lactofen. Weed Science, 41, 23-27.

Wortman, S. E. (2014). Integrating weed and vegetable crop management with multifunctional air-propelled abrasive grits. Weed Technology, 28, 243-252. https://doi.org/10.1614/WT-D-13-00105.1

Supporting information Additional supporting information follows. 


\title{
Supplementary Information
}

Manuscript: Economics of Herbicide Programs for Weed Control in Conventional, Glufosinate, and Dicamba/Glyphosate-Resistant Soybean Across Nebraska

\author{
Supplemental Table 1. Soybean injury ratings at 14 and 28 \\ days after pre-emergence (DAPRE) herbicide application in \\ field experiments conducted across five locations in \\ Nebraska to determine economics of herbicide programs in \\ conventional, glufosinate, and dicamba/glyphosate-resistant \\ soybean in 2018 and 2019. a,b,c,d

\begin{tabular}{|c|c|c|}
\hline Herbicide Program & $\begin{array}{c}14 \\
\text { DAPRE }\end{array}$ & $\begin{array}{c}28 \\
\text { DAPRE }\end{array}$ \\
\hline PRE & & $70-$ \\
\hline Nontreated control & 0.0 & 0.0 \\
\hline Weed-free control & 1.4 & 4.0 \\
\hline $\begin{array}{l}\text { Sulfentrazone/S-metolachlor }+ \\
\text { metribuzin }\end{array}$ & 2.4 & 2.7 \\
\hline $\begin{array}{l}\text { Chlorimuron/flumioxazin/ } \\
\text { thifensulfuron-methyl }\end{array}$ & 1.2 & 3.1 \\
\hline $\begin{array}{l}\text { Flumioxazin/pyroxasulfone }+ \\
\text { metribuzin }\end{array}$ & 1.0 & 3.1 \\
\hline $\begin{array}{l}\text { Chlorimuron/flumioxazin/ } \\
\text { metribuzin }\end{array}$ & 1.0 & 3.2 \\
\hline $\begin{array}{l}\text { Imazethapyr/pyroxasulfone/ } \\
\text { saflufenacil }\end{array}$ & 1.7 & 3.8 \\
\hline $\begin{array}{r}P \text {-value } \\
\text { Site-years (n) }\end{array}$ & $\begin{array}{l}\mathbf{0 . 9 1 5} \\
6(672)\end{array}$ & $\begin{array}{l}\mathbf{0 . 7 1 1} \\
6(672)\end{array}$ \\
\hline
\end{tabular} \\ ${ }^{a}$ Abbreviations: DAPRE, day after PRE herbicide application. \\ ${ }^{\mathrm{b}}$ Crop injury data at 14 and 28 DAPRE were combined for all \\ study locations in 2018 and 2019. Data were logit transformed \\ before analysis; however back transformed values are presented \\ based on interpretations of transformed data. \\ ${ }^{\mathrm{c}}$ Means presented within the same column with no common letters \\ are significantly different according to estimated marginal means \\ with Sidak confidence-level adjustments and Tukey $P$-value \\ adjustments. \\ ${ }^{\mathrm{d}}$ Mean separation for crop injury at 14 and 28 DAPRE included \\ comparisons to the weed-free control.
}




\begin{tabular}{|c|c|c|c|c|c|}
\hline $\begin{array}{l}\text { Supplemental Table 2. S } \\
\text { (DAPOST) herbicide appl } \\
\text { Nebraska to determine eco } \\
\text { dicamba/glyphosate-resist }\end{array}$ & $\begin{array}{l}\text { oybean injury } \\
\text { ication in field } \\
\text { nomics of herb } \\
\text { ant soybean in }\end{array}$ & $\begin{array}{l}\text { ings at } 1 \\
\text { perimen } \\
\text { ide prog } \\
18 \text { and } 2\end{array}$ & $\begin{array}{l}\text { in conve } \\
\text { a,b,c,d }\end{array}$ & $\begin{array}{l}\mathrm{r} \text { post-er } \\
\text { s five lo } \\
\text { al, glufe }\end{array}$ & $\begin{array}{l}\text { gence } \\
\text { ons in } \\
\text { ate, and }\end{array}$ \\
\hline & Cultivar & $14 \mathrm{D}$ & POST & $28 \mathrm{D}$ & $\overline{\mathrm{POST}}$ \\
\hline Herbicide Program & HR-Traits & PHYDEF & PHYNEC & PHYDEF & PHYNEC \\
\hline POST & & & & & \\
\hline Dicamba + glyphosate & DR & $0.0 \mathrm{a}$ & $0.0 \mathrm{a}$ & $0.0 \mathrm{a}$ & $0.0 \mathrm{a}$ \\
\hline Glyphosate & DR & $0.0 \mathrm{a}$ & $0.0 \mathrm{a}$ & $0.0 \mathrm{a}$ & $0.0 \mathrm{a}$ \\
\hline Glufosinate & GLU-R & $13.2 \mathrm{~b}$ & $0.0 \mathrm{a}$ & $11.5 \mathrm{~b}$ & $0.0 \mathrm{a}$ \\
\hline $\begin{array}{l}\text { Acetochlor + clethodim }+ \\
\text { lactofen }\end{array}$ & $\mathrm{CON}$ & $12.7 \mathrm{~b}$ & $11.7 \mathrm{~b}$ & $11.9 \mathrm{~b}$ & $8.5 \mathrm{~b}$ \\
\hline & $P$-value & $<0.001$ & $<0.001$ & $<0.001$ & 0.031 \\
\hline & Site-years (n) & $6(672)$ & $6(672)$ & $6(672)$ & $6(672)$ \\
\hline $\begin{array}{l}\text { a Abbreviations: DAPOST, } \\
\text { glufosinate-resistant; DGR, } \\
\text { phytotoxic deformities; PHY } \\
\text { b Crop injury data at } 14 \text { and } 2 \\
\text { were logit transformed befor } \\
\text { interpretations of transformec } \\
{ }^{\mathrm{c}} \text { Means presented within the } \\
\text { to estimated marginal means } \\
\text { d Mean separation for crop in } \\
\text { and weed-free control. }\end{array}$ & $\begin{array}{l}\text { ay after POST he } \\
\text { licamba/glyphosa } \\
\text { NEC, phytotoxic } \\
28 \text { DAPOST wer } \\
\text { analysis; howe } \\
\text { d data. } \\
\text { same column wi } \\
\text { with Sidak confi } \\
\text { jury at } 14 \text { and } 28\end{array}$ & $\begin{array}{l}\text { bicide appl } \\
\text { e-resistant; } \\
\text { necrosis. } \\
\text { combined } \\
\text { er back tran } \\
\text { no comm } \\
\text { ence-level }\end{array}$ & $\begin{array}{l}\text { ion; CON, c } \\
\text {, Herbicide } \\
\text { all study loc } \\
\text { rmed values } \\
\text { etters are sis } \\
\text { ustments anc }\end{array}$ & $\begin{array}{l}\text { entional; C } \\
\text { stant; PHY } \\
\\
\text { ns in } 2018 \\
\text { presented } \\
\text { cantly diff } \\
\text { key } P \text {-valu }\end{array}$ & $\begin{array}{l}\text { J-R, } \\
\text { EF, } \\
2019 . \text { Data } \\
\text { ed on } \\
\text { ht according } \\
\text { djustments. } \\
\text { eated control }\end{array}$ \\
\hline
\end{tabular}

